\title{
Impact of increased horizontal resolution in coupled and atmosphere-only models of the HadGEM1 family upon the climate patterns of South America
}

\author{
Maria de Souza Custodio ${ }^{1,2}$ - Rosmeri Porfírio da Rocha ${ }^{2}$ Tércio Ambrizzi ${ }^{2}$. \\ Pier Luigi Vidale $^{3}$. Marie-Estelle Demory ${ }^{3}$
}

Received: 4 September 2015 / Accepted: 10 July 2016 / Published online: 21 July 2016

(C) Springer-Verlag Berlin Heidelberg 2016

\begin{abstract}
This study investigates the impact of increased horizontal resolution in coupled and atmosphere-only global climate models on the simulation of climate patterns in South America (SA). We analyze simulations of the HadGEM1 model family with three different horizontal resolutions in the atmosphere- $\mathrm{N} 96\left(\sim 135 \mathrm{~km}\right.$ at $\left.50^{\circ} \mathrm{N}\right)$, $\mathrm{N} 144(\sim 90 \mathrm{~km})$ and $\mathrm{N} 216(\sim 60 \mathrm{~km})$ - and two different resolutions in the ocean $-1^{\circ}$ and $1 / 3^{\circ}$. In general, the coupled simulation with the highest resolution $(60 \mathrm{~km}$ in the atmosphere and $1 / 3^{\circ}$ in the ocean) has smaller systematic errors in seasonal mean precipitation, temperature and circulation over SA than the atmosphere-only model at all resolutions. The models, both coupled and atmosphere-only, properly simulate spatial patterns of the seasonal shift of the Intertropical Convergence Zone (ITCZ), the formation and positioning of the South Atlantic Convergence Zone (SACZ), and the subtropical Atlantic and Pacific highs. However, the models overestimate rainfall, especially in the ITCZ and over the western border of high-elevation areas such as southern Chile. The coupling, combined with higher resolution, result in a more realistic spatial pattern of rain, particularly over the Atlantic ITCZ and the continental branch of the SACZ. All models correctly simulate the phase and amplitude of the annual cycle of precipitation
\end{abstract}

Maria de Souza Custodio

mariacustodio@fc.unesp.br

1 Departamento de Física, Universidade Estadual Paulista and Centro de Meteorologia de Bauru (IPMet), Bauru, São Paulo, Brazil

2 Departamento de Ciências Atmosféricas, Universidade de São Paulo, São Paulo, Brazil

3 Department of Meteorology, National Centre for Atmospheric Science, University of Reading, Reading, UK and air temperature over most of South America. The overall results show that despite some problems, increasing the resolution in the HadGEM1 model family results in a more realistic representation of climate patterns over South America and the adjacent oceans.

Keywords South America · Coupled · Atmospheric · Resolution

\section{Introduction}

South America (SA) is a continent with great latitudinal extension, with a diversified surface physiography and a large mountain range, the Andes, located on its western side, extending from $60^{\circ} \mathrm{S}$ to the tropics. The continent has tropical, sub-tropical and extratropical characteristics, and because of its large area, it is influenced by various dynamic systems with different spatial and temporal scales, resulting in differing climatic regimes in its sub-regions. Prominent among the wide variety of systems that determine the climate of SA are the South Atlantic Convergence Zone (SACZ; Kodama 1992; Satyamurty et al. 1998; Carvalho et al. 2004), the Intertropical Convergence Zone (ITCZ; Uvo and Nobre 1989; Waliser and Gautier 1993), mesoscale convective systems (MCS; Machado and Rossow 1993; Sakamoto et al. 2011), upper-level vortexs (Gan and Kousky 1986), and the Bolivian High (BH; Gutmann and Schwerdtfeger 1965; Lenters and Cook 1997). It is also important to highlight the El Niño/Southern Oscillation (ENSO) phenomenon and sea surface temperature (SST) variability, which directly affect SA climate variability and are among the main challenges for climate modeling (Grimm and Silva Dias 1995; Ambrizzi et al. 1995). 
The large-scale seasonal patterns of meteorological variables are constantly being analyzed across the globe, and a more realistic representation of their characteristics still remains a challenge for climate modeling. Among the systems that determine the climate variability and are not yet well simulated by climate models, despite having well defined seasonal cycles, are the zones of convergence. Simulations of these systems are constantly being evaluated in order to understand model errors. For example, errors in intensity, position and displacement of the convergence zones acting over SA have been discussed by Custodio et al. (2012) and Bombardi and Carvalho (2009). Furthermore, coupled climate models share systematic errors in the breaking up of the ITCZ (Ma et al. 1996; Yu and Mechoso 1999; Cavalcanti et al. 2002; Biasutti et al. 2006; Silva et al. 2014) and the representation of circulation patterns and rain in the Andes' highlands. There is a general agreement that global climate models require constant evaluation in order to identify simulations errors and indicate directions for improvement.

Proceeding from the Intergovernmental Panel on Climate Change Fourth Assessment Report (IPCC AR4; Solomon et al. 2007) and the Coupled Model Intercomparison Project-Phase 3 (CMIP3), General Circulation Models (GCM) have been improved and their resolutions refined for CMIP5. IPCC AR5 (IPCC 2013) show that the ability of these models to simulate surface temperatures have increased in many, but not all, aspects with respect to AR4. CMIP5 models also showed an improvement in the mean annual rainfall, compared to CMIP3, with an increase in global spatial correlation between simulations and observations. However, precipitation continues to present large errors at regional scale, and their evaluation at such scale remains difficult due to observational uncertainties (Hegerl et al. 2015).

Increasing horizontal resolution in GCMs is constantly being tested in climate modeling centers around the world (e.g. Shaffrey et al. 2009; Delworth et al. 2012; Kinter et al. 2013; Bacmeister et al. 2014; Mizielinski et al. 2014; Small et al. 2014). One of the first initiatives to simultaneously increase the resolution in both the atmosphere and the ocean in coupled models took place within the UK High Resolution Global Environmental Modelling (HiGEM) project (Shaffrey et al. 2009) and the UK-Japan Climate Collaboration (Roberts et al. 2009).

According to Roberts et al. (2009), increasing horizontal resolution in the HadGEM1 model family improved some aspects of the simulations such as tropical instability waves and their interaction with the tropical atmosphere. These authors point out that the interaction between the tropical instability waves and the response of near-surface winds impact the average state of the equatorial Pacific Ocean and therefore the average global climate and ENSO. The ability of the atmosphere to respond to small-scale structures in the SST in a more realistic way was apparent in studies of Shaffrey et al. (2009) and Roberts et al. (2009). High-resolution atmosphere-only simulations have shown significant improvements in many features, such as in the representation of tropical cyclones trajectories and in the spatial distribution of precipitation, particularly where orographic effects are important (Pope and Stratton 2002; Jung et al. 2006, 2012; Manganello et al. 2012; Kopparla et al. 2013; Van Haren et al. 2015). For the ocean, resolution affects the representation of ocean eddies, which can result in improvements in wind direction, circulation and westerly currents (originating from the west; Shaffrey et al. 2009).

In SA, GCMs have shown some ability to predict seasonal rainfall, especially in the northeast of Brazil due to its strong relationship to SST anomalies (Nobre et al. 2001; Moura and Hastenrath 2004). Coupled GCMs depict major problems in the simulation of SA rainfall, particularly in the intensity, location and seasonal evolution of the SACZ, as well as in the exact quantification of seasonal mean precipitation over the major basins of the continent (Vera et al. 2006). For example, CMIP3 GCMs do not reproduce the rainfall maximum observed over southeastern SA (SESA) during the cold season (Vera et al. 2006; Seth et al. 2010). According to Cavalcanti et al. (2002), the global model CPTEC-COLA underestimates (overestimates) rainfall in the tropical (subtropical) sectors of the convergence zones. On the other hand, this model overestimates precipitation over the Andes and in northeastern Brazil, while a large deficit of rainfall was noted in the interior of the South American continent, including the Amazon basin.

The coupled models of the HadGEM1 family with finer horizontal grids (135 and $90 \mathrm{~km}$ in the atmosphere) were previously analyzed over South America by Custodio et al. (2012), albeit with a slightly different physical formulation, and pointed out some improvement in the representation of migration and positioning of the ITCZ and Pacific and Atlantic subtropical highs. Furthermore, the models reproduce the location and seasonal evolution of the SACZ well, indicating significant improvements over coarser horizontal resolution models (Vera et al. 2006; Seth et al. 2010). In contrast, the Brazilian climate model (BESM-OA2.3) developed by CPTEC/INPE, with intermediate horizontal grid $\left(1.875^{\circ}\right.$ in the atmosphere), analyzed by Nobre et al. (2013), showed errors similar to those of other coupled models, such as a double ITCZ displaced to the south and an almost absent South Pacific Convergence Zone (SPCZ). In addition, BESM-OA2.3 simulated excessive rainfall over the oceans and a deficit over the continent, especially over the Amazon basin.

The objective of the present study is to evaluate the impact of horizontal resolution in global coupled and 
Table 1 Configurations of the global climate models from the HadGEM family and the nomenclatures used hereafter to refer to each simulation

\begin{tabular}{llll}
\hline Short name of configuration & $\begin{array}{l}\text { Resolution }\left(\text { Lat } \times \text { Lon, in }{ }^{\circ}\right) \text { in } \\
\text { atmosphere and ocean }\end{array}$ & $\begin{array}{l}\text { Resolution in km }(\text { at } 50 \mathrm{~N}) \text { atmosphere/ } \\
\text { ocean }(\mathrm{km})\end{array}$ & $\begin{array}{l}\text { Simulation period }(\text { years }) \\
\text { Coupled models }\end{array}$ \\
HadGEM & $\begin{array}{l}\mathrm{N} 96\left(1.25^{\circ} \times 1.875^{\circ}\right) 1^{\circ} \times 1^{\circ}(\text { gradually } \\
\left.\text { increased to } 1 / 3^{\circ} \text { at the Equator }\right)\end{array}$ & $135 / 100$ & 100 \\
HiGEM & $\mathrm{N} 144\left(0.83^{\circ} \times 1.25^{\circ}\right) 1 / 3^{\circ} \times 1 / 3^{\circ}$ & $90 / 30$ & 100 \\
NUGEM & $\mathrm{N} 216\left(0.55^{\circ} \times 0.83^{\circ}\right) 1 / 3^{\circ} \times 1 / 3^{\circ}$ & $60 / 30$ & 22 \\
Atmosphere only models & $\mathrm{N} 96\left(1.25^{\circ} \times 1.875^{\circ}\right)$ & 135 & $24(1979-2002)$ \\
HadGAM & $\mathrm{N} 144\left(0.83^{\circ} \times 1.25^{\circ}\right)$ & 90 & $24(1979-2002)$ \\
HiGAM & $\mathrm{N} 216\left(0.55^{\circ} \times 0.83^{\circ}\right)$ & 60 & $26(1979-2004)$ \\
NUGAM & & &
\end{tabular}

atmosphere-only models on the climatology of SA. The simulations were performed with the HadGEM1 model family using various horizontal grid spacing: N96 $\left(\sim 135 \mathrm{~km}\right.$ at $\left.50^{\circ} \mathrm{N}\right), \mathrm{N} 144\left(\sim 90 \mathrm{~km}\right.$ at $\left.50^{\circ} \mathrm{N}\right), \mathrm{N} 216(\sim 60 \mathrm{~km}$ at $50^{\circ} \mathrm{N}$ ) in the atmosphere and $1^{\circ}$ (gradually increased to $1 / 3^{\circ}$ at the equator) and $1 / 3^{\circ}$ globally in the ocean. Two important aspects are addressed here: (1) does increased horizontal resolution in this model impact the simulated climate over South America; (2) what is the impact of SST on this climatology?

\section{Materials and methods}

\subsection{Model}

The simulations described in this paper share a common model based on the UK Met Office Hadley Centre Global Environmental Model version 1, HadGEM1 (Johns et al. 2006; Martin et al. 2006; Ringer et al. 2006), a fully coupled Atmosphere-Ocean GCM. HadGEM1, referred to as HadGEM here, was developed for the IPCC AR4 at a horizontal grid spacing of $1.25^{\circ}$ latitude $\times 1.875^{\circ}$ longitude (N96) in the atmosphere and $1^{\circ} \times 1^{\circ}$ in the ocean (augmented to $1 / 3^{\circ}$ meridionally at the equator; Table 1 ). From HadGEM, two higher-resolution configurations were developed in the context of high-resolution modelling programs developed in partnership between the Natural Environment Research Council (NERC) and the Met Office Hadley Centre: (1) HiGEM developed under the UK High Resolution Global Environmental Modelling project at a resolution of $0.83^{\circ}$ latitude $\times 1.25^{\circ}$ longitude $(\mathrm{N} 144)$ in the atmosphere and $1 / 3 \times 1 / 3^{\circ}$ in the ocean (Shaffrey et al. 2009); (2) NUGEM developed in the context of the UK-Japan Climate Collaboration at a resolution of $0.55^{\circ}$ latitude $\times 0.83^{\circ}$ longitude (N216) in the atmosphere and $1 / 3 \times 1 / 3^{\circ}$ in the ocean (Roberts et al. 2009). HiGEM and NUGEM were developed based on a number of small modifications in the dynamical core of the "parent" configuration, HadGEM, necessary for enabling the increased resolution in the ocean and atmosphere, such as the time step (Roberts et al. 2009; Demory et al. 2014), but they share identical physical parametrizations to allow a clean comparison of the effect of resolution.

The atmospheric component of HadGEM has a nonhydrostatic dynamical core with semi-Lagrangian transport, where the equations are discretized on the Arakawa $\mathrm{C}$ grid. In addition, the model includes an iterative scheme for aerosols. The parameterizations of the boundary layer and convective schemes are virtually identical to those used in HadCM3 (Pope et al. 2000). HadGEM has 38 vertical levels with the top of the model set at $39 \mathrm{~km}$; thus the stratosphere is not completely resolved. HadGEM uses the second version of the UK Met Office Surface Exchange Scheme (MOSES-II; Cox et al. 1999; Martin et al. 2006) to represent the surface processes allowing the description of the heterogeneous coverage of the Earth's surface by the use of nine different surface types.

The oceanic component of HiGEM/NUGEM follows that used in HadGEM (Johns et al. 2006), but with a higher horizontal resolution $\left(1 / 3^{\circ}\right.$ globally) and some additional improvements. The oceanic model is formulated on a spherical latitude-longitude grid using 40 vertical levels spaced unevenly, with a higher resolution near the surface to better address the mixed layer and the ocean-atmosphere interaction processes. The maximum ocean depth is $5500 \mathrm{~m}$. A more detailed description of the ocean model can be obtained in Shaffrey et al. (2009).

The formulation of the sea ice also follows that used in HadGEM. However, the values of some parameters and the introduction of sub-schemes for space and time for the ice dynamics were changed. Rather than existing as a separate sub-model, part of the ice is treated within the ocean model, and a small part is resolved by the atmospheric model. The ocean model addresses the dynamics, redistribution mechanics, and thermodynamics of the sea ice, 


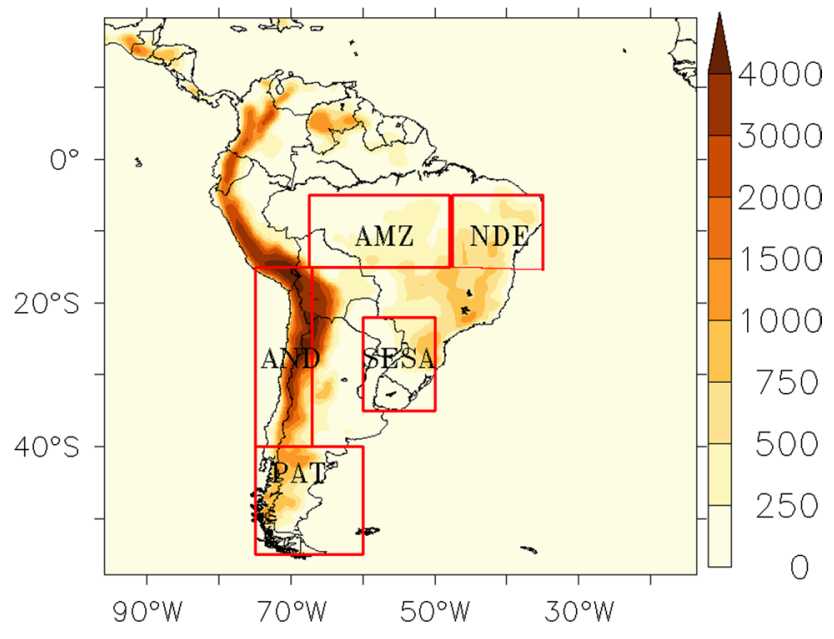

Fig. 1 South America topography (shaded, in m) and location of five subdomains for annual cycle analysis

while the atmospheric model calculates the ice-air fluxes and the temperature of the ice surface using the time step of the atmosphere to allow the representation of the diurnal cycle of the ice. Mean fields are then transferred to the ocean model at each coupling time step (once a day). Further details on the sea ice component of HadGEM can be obtained in McLaren et al. (2006).

\subsection{Simulations}

The present study analyze and compare six simulations of the HadGEM series using the same dynamical core, and the same physical parameterization and radiative forcing. All simulations used the radiative forcing (e.g. climatological annual cycle of present-day greenhouse gases and aerosols) of the 1990s, with the model running freely in response to this forcing. The simulations differ only in being either coupled or atmosphere-only and in terms of horizontal grid spacings in the atmosphere and ocean (see details and nomenclature in Table 1). In the atmosphere-only simulations, referred to as HadGAM, HiGAM and NUGAM (Table 1), SST and sea ice are prescribed by the Atmospheric Model Intercomparison Project (AMIP II; Gates et al. 1999), from 1979 to 2002 with a horizontal resolution of $1^{\circ} \times 1^{\circ}$.

The characteristics of austral summer (DecemberJanuary-February-DJF) and austral winter (June-JulyAugust-JJA) climates are analyzed over SA, while the annual cycle is evaluated over the five subdomains shown in Fig. 1. The regions are identified as: AMZ (Amazon), NDE (Northeast), SESA (Southeastern South America), Andes (AND) and Patagonia (PAT). The climate patterns are classified as precipitation, temperature and circulation at low and high levels.

\subsection{Data}

The climate simulations are compared to different observations, which have different spatial and temporal resolutions. For seasonal climatology and precipitation annual cycle, the datasets used awere: (a) Climate Prediction CenterMerged Analysis of Precipitation (CMAP; horizontal resolution: 2.5' ; period: 1979-2008; Xie and Arkin 1996); (b) Climate Research Unit (CRU; horizontal resolution: $0.5^{\circ}$; period: 1979-2002; Mitchell and Jones 2005); (c) Global Precipitation Climatology Project (GPCP; horizontal resolution: 2.5'; period: 1979-2008; Quartly et al. 2007); (d) Climate Prediction Center (CPC; horizontal resolution: $1^{\circ}$; period: 1979-2005; Chen et al. 2008); (e) Tropical Rainfall Measuring Mission (TRMM; horizontal resolution: 0.04 ; period: $1998-2009$ ) product 3B31 (dataset available in http://www.geog.ucsb.edu/ bodo/TRMM/; Bookhagen $\mathrm{B}$, in review). For air temperature, we use reanalysis and observational datasets: (a) the National Centers for Environmental Prediction (NCEP; horizontal resolution: 2.5 ; period: 1979-2008; Kalnay et al. 1996); (b) European Centre for Medium-Range Weather Forecasts (ECMWF) ERA-Interim, hereafter ERAIN (horizontal resolution: 1.5'; period: 1979-2008; Dee et al. 2011); (c) CRU (as described above). Circulation at high and low levels is compared with ERAIN. The validation of seasonal patterns and annual cycles uses the monthly and seasonal mean values of CMAP, GPCP, CRU and CPC for precipitation and ERAIN, CRU and NCEP for air temperature.

\section{Results}

\subsection{Seasonal climatology: precipitation}

According to Figs. 2 and 3, the seasonal migration of the ITCZ in the coupled simulations is similar to that observed (Figs. 2a-b, 3a-b), although there are some differences between simulations and observations in the rain intensity from this system. In both summer (Fig. 2b) and winter (Fig. 3b), the coupled models overestimate (underestimate) rain intensity in the northern (southern) parts of the Pacific ITCZ compared to observations. In comparison to TRMM, which has a high spatial resolution, the differences between the simulations and analysis (or errors) are smaller. The north-south shifting of the ITCZ is correctly simulated by both the coupled models and the atmosphere-only models. However, the north-south extent of the ITCZ near the north coast of SA is generally greater in the atmosphere-only simulations than in the observations (Fig. 3g, h). Moreover in the austral summer, the Atlantic ITCZ is positioned further south, near the north-northeastern coast of Brazil, in the coupled models. 
(a)

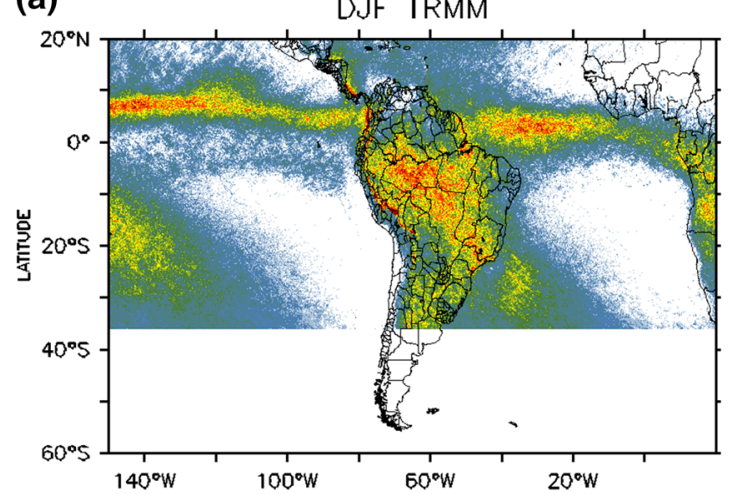

(c)

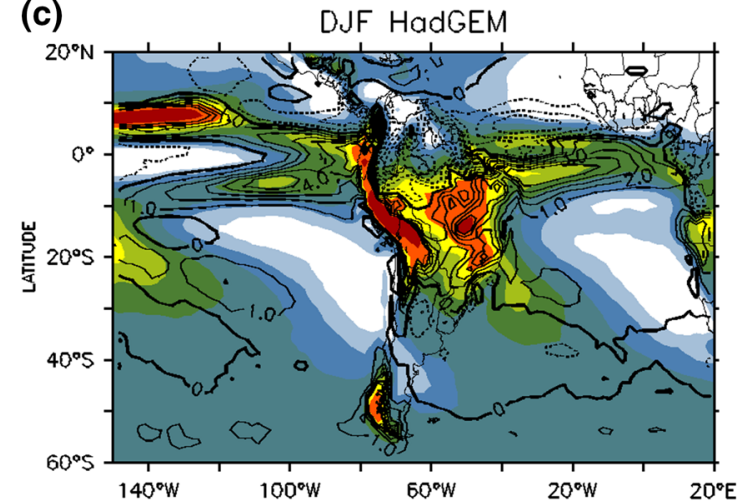

(d)

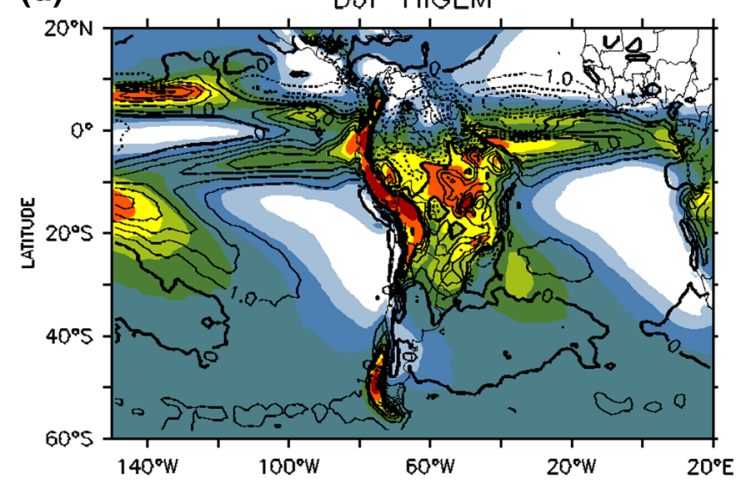

(e)

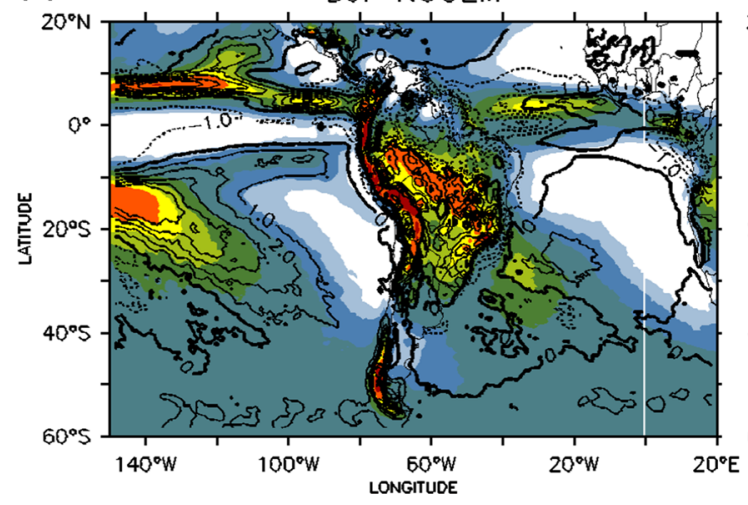

Fig. 2 Seasonal climatology of precipitation $\left(\mathrm{mm} \mathrm{day}^{-1}\right)$ in South America in the summer (DJF) from TRMM (a) and the observations (b), coupled models HadGEM (c), HiGEM (d) and NUGEM (e), and atmospheric models HadGAM (f), HiGAM (g) and NUGAM (h). The
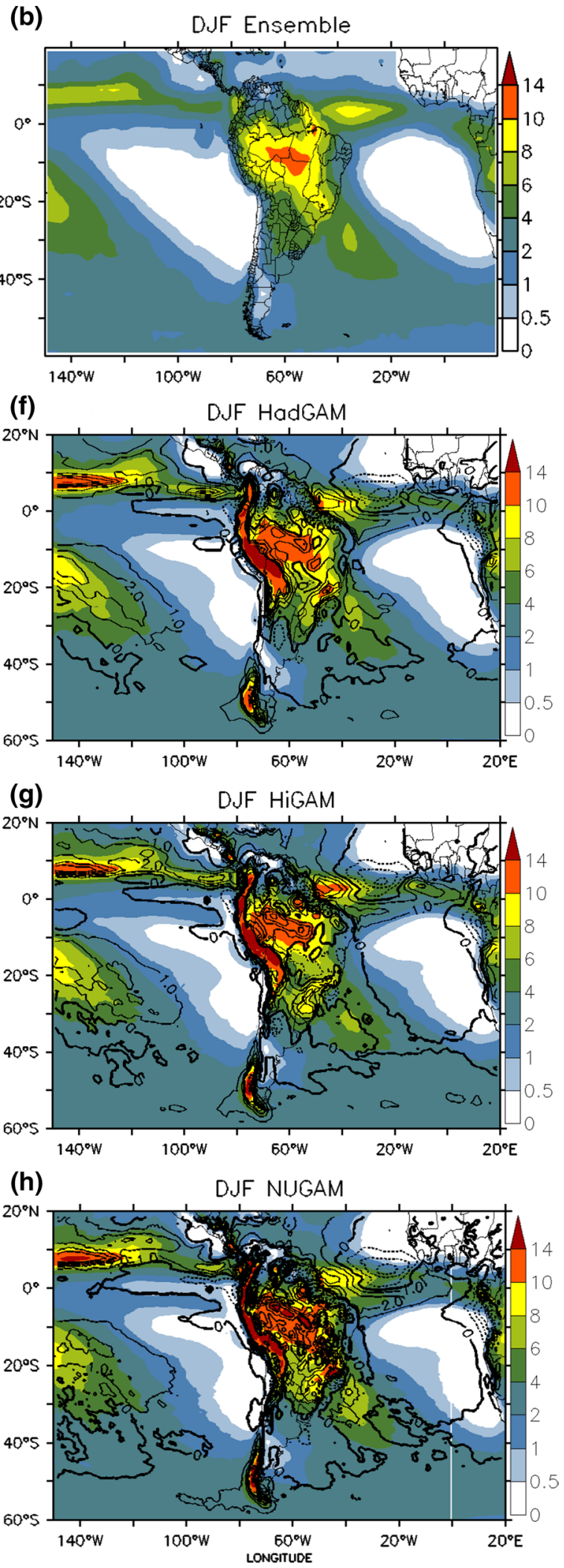

contours lines are the biases of the models against the observational ensemble (dashed lines are negative values and solid lines are positive values) 
(a)

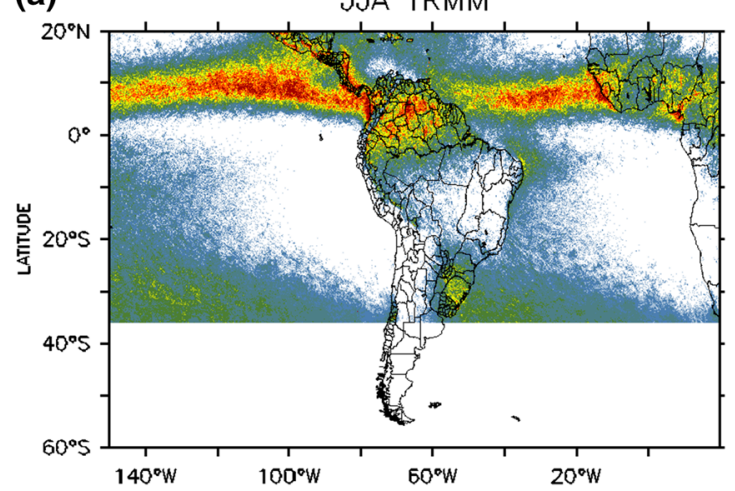

(c)

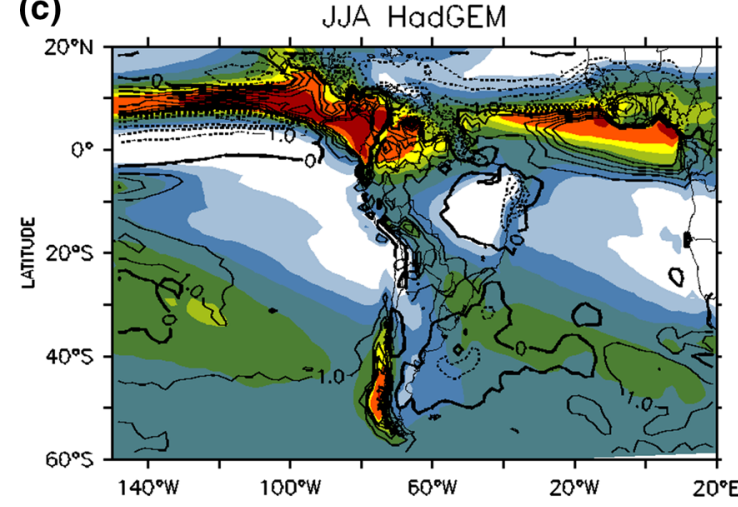

(d)

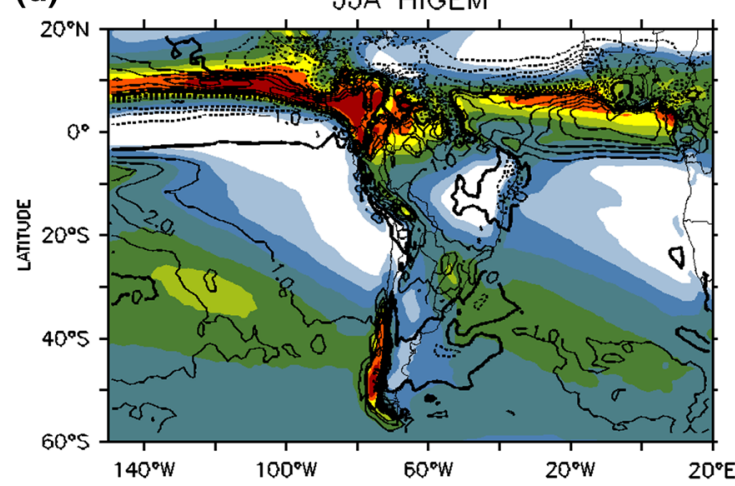

(e)

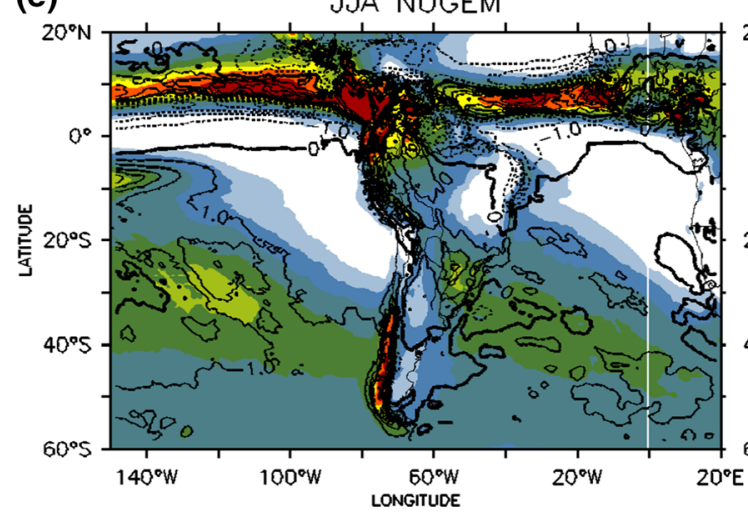

Fig. 3 Seasonal climatology of precipitation $\left(\mathrm{mm} \mathrm{day}^{-1}\right)$ in South America in the winter (JJA) from TRMM (a) and the observations (b), coupled models HadGEM (c), HiGEM (d) and NUGEM (e), and atmospheric models HadGAM (f), HiGAM (g) and NUGAM (h). The
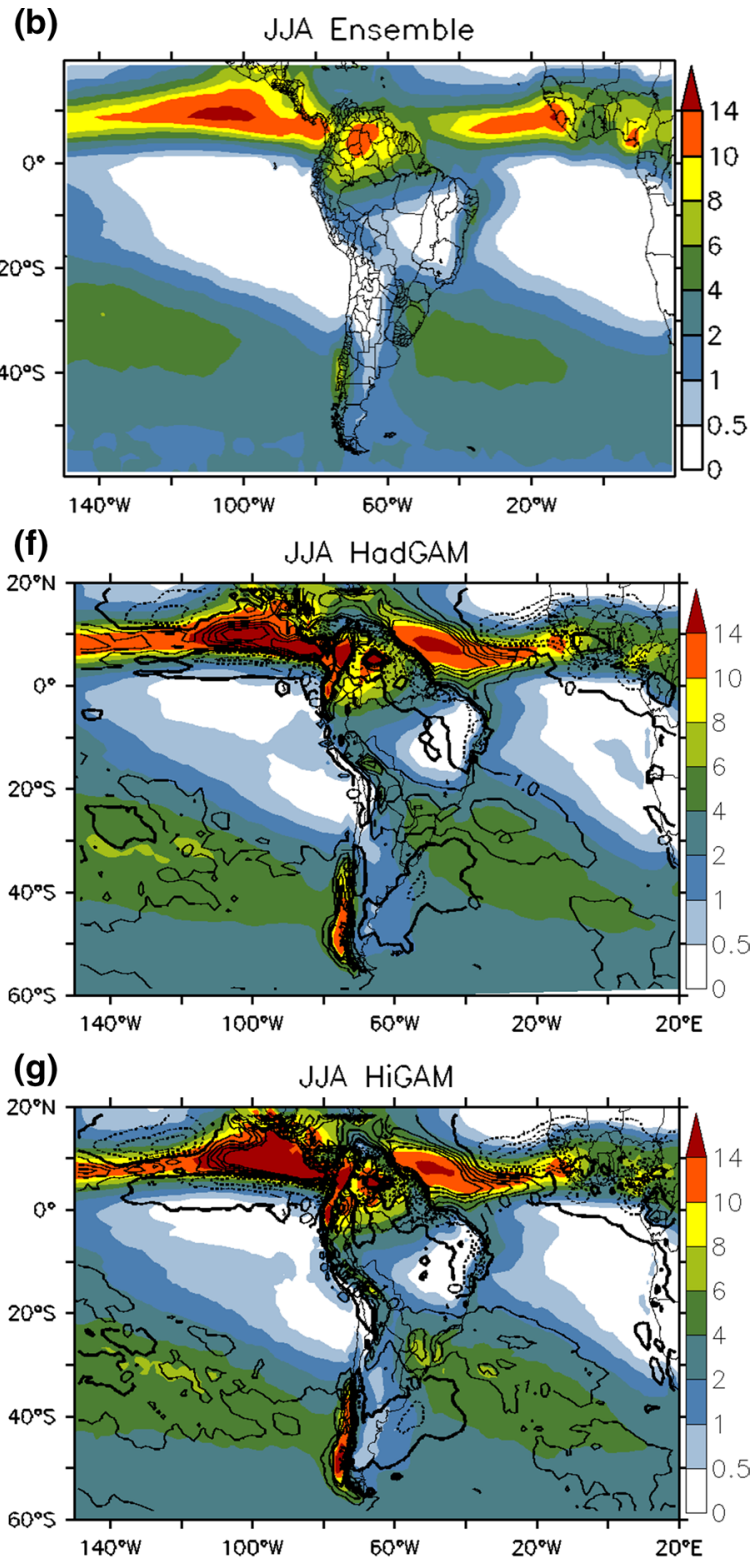

(h)

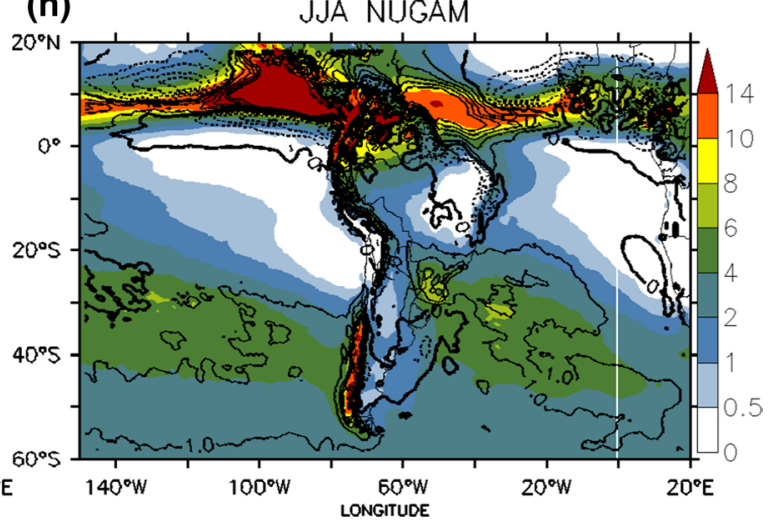

contours lines are the biases of the models against the observational ensemble (dashed lines are negative values and solid lines are positive values) 
In DJF, the ITCZ has one precipitation maximum in the Atlantic, centered at $\sim 25-30^{\circ} \mathrm{W} /-5^{\circ} \mathrm{N}$, and is more intense in the Pacific toward the west but weakens near the west coast of Central America (Fig. 2a-b). In both basins, the spatial precipitation patterns in the ITCZ simulated by NUGEM (Fig. 2e) is closer to observations (Fig. 2a, b) than the other lower resolution coupled (Fig. 2c, d) and low- and high-resolution atmosphere-only (Fig. 2f-h) simulations. This indicates the importance of both the horizontal resolution and the ocean-atmosphere coupling in the organization of the rain in the ITCZ. In addition, comparing NUGEM to NUGAM, there is a clear indication that the highfrequency SST variability, resulting from the daily coupling in NUGEM, is more important for reproducing the observed precipitation patterns than prescribing monthlymean observed SSTs in the atmosphere-only model. The magnitude of rainfall simulated by NUGEM in the ITCZ is also closer to observations than the other models. The rain area in the Atlantic ITCZ is centered at $\sim 3-4^{\circ} \mathrm{N} / 30^{\circ} \mathrm{W}$ in NUGEM, which corresponds to the latitude of convergence of trade winds in the lowermost troposphere (the layer between 1000 and $900 \mathrm{hPa}$ ). This indicates that, in the coupling-resolution combination, rain is responding to the correct positioning of the large-scale low-level wind convergence (figure not shown) and the associated convective systems, a response that is not as clearly seen in the other simulations. Using a coupled regional model at high resolution $\left(1 / 4^{\circ}\right)$, Seo et al. (2008) obtained similar results to that of NUGEM, i.e. a more realistic ITCZ in the tropical Atlantic. According Seo et al. (2008), this response occurs provided that the convection associated with the African Easterly Waves reinforces the ITCZ precipitation in an environment in which large-scale convergence at low levels is also more intense.

The low-resolution coupled simulations used in this study, HadGEM and HiGEM, show a break in the Pacific ITCZ in Austral summer (Fig. 2c, d), a common error in global models, which can be attributed to their adjustment in the mass flux. Since the models overproduce rain around $5-10^{\circ} \mathrm{N}$, they compensate this excess with subsidence in the nearby region, creating a dry bias (Gandu and Silva Dias 1998; Cavalcanti et al. 2002). Some studies (e.g. Ma et al. 1996; Yu and Mechoso 1999; Li et al. 2002) also attribute the double ITCZ to an underestimation in the stratus cloud cover on the Peruvian coast in the southeast Pacific, a common problem in atmosphere-only GCMs that directly affects the simulation of the ITCZ. As a result of the increased horizontal resolution, there is less break in the ITCZ in NUGEM. In the atmosphere-only simulations, the equatorial Pacific Ocean rainfall in the ITCZ is less intense, thus reducing the double ITCZ (Fig. 2f-h). The spatial pattern of the ITCZ and the magnitude of the rain show little change with increasing horizontal resolution, and even worsens slightly in NUGAM. The double ITCZ present in the coupled models was also identified by Custodio et al. (2012) in a previous version of the HadGEM model family. However, with respect to the intensity of the ITCZ, the models considered in this study show wetter biases than those analyzed by Custodio et al. (2012), especially over the Atlantic Ocean.

In DJF, the presence of the SACZ in the observations (Fig. 2a, b) is indicated by a region of high rainfall that extends from southern Amazonia to the subtropical Atlantic Ocean, where its oceanic branch is situated on the southeast coast of Brazil (Kodama 1992; Satyamurty et al. 1998; Carvalho et al. 2004). As for the flow at $850 \mathrm{hPa}$ (Fig. 6), northwest winds carry moisture from the Amazon region to the subtropics of SA, which together with the western branch (northeast wind) of the South Atlantic Subtropical High favor the release of intense convective activity in the tropics and subtropics of South America. Figure 2 makes it clear that the coupled simulations, HadGEM, HiGEM and NUGEM, produce a spatial pattern of the SACZ that is closer to the observations. Additionally, the grid refinement in NUGEM implies greater similarities with TRMM, most notably in the representation of the northwest/southeast extent of the continental SACZ. The wet biases in the continental branch of SACZ are also smaller in NUGEM than in the other coupled simulations, HadGEM and HiGEM. Regarding the atmosphere-only models, the high-horizontal resolution used in NUGAM tends to increase rainfall over both the continental and oceanic regions of the SACZ, thereby increasing the wet biases of the simulation.

During Austral winter, the spatial precipitation patterns in the oceanic part of the ITCZ simulated by the coupled models are closer to observations than the atmosphere-only models (Fig. 3). The coupled models simulate more rainfall in the eastern sector of the tropical Atlantic basin, while the atmosphere-only models simulate a maximum of rain in the western sector of this basin. In general, atmosphereonly models underestimate precipitation in the ITCZ in the southwest sector of the North Atlantic Ocean, near the west coast of Africa, compared to observations. This error in simulating the Atlantic ITCZ is common among atmosphere-only global climate models. Biasutti et al. (2006) identified a similar pattern, which was attributed to the difficulty in representing the correct relationship between SST and precipitation in the Atlantic region in atmosphere-only models. Since the sea surface is warmer in the southwestern equatorial Atlantic, models tend to simulate the maximum precipitation over this region, indicating a direct relationship between SST and precipitation, which affects the wind convergence and thus the location of the ITCZ (Biasutti et al. 2006).

Both coupled and atmosphere-only models simulate the extensive dry area over the continent, from the northeast 
to the southeast of Brazil (north of $20^{\circ} \mathrm{S}$ ) in Austral winter (Fig. 3), with some differences in the size of this dry area. The coupled models simulate the extent of this area quite well compared to the observations ensemble (Fig. 3b) and slightly less compared to TRMM (Fig. 3a). On the narrow band between $5^{\circ}-18^{\circ} \mathrm{S}$ and $41^{\circ}-35^{\circ} \mathrm{W}$, known as the eastern coast of Northeastern Brazil, the rainy season occurs mainly from April to July (Rao et al. 1993). In this region, the observations in JJA (Fig. 3a, b) show the occurrence of intense rainfall. According to Kousky (1980), this rain would result from the convergence of the southeasterly trade winds and the nocturnal land breeze, since it peaks during night. This nocturnal maximum of rainfall was also confirmed by TRMM-PR (Tropical Rainfall Measuring Mission-Precipitation Radar; da Rocha et al. 2009). More recent studies also indicate the contribution of easterly waves propagating over the tropical Atlantic to the rain in this area (Kayano 2003; Diedhiou et al. 2010; Torres and Ferreira 2011; Gomes et al. 2015), from cyclonic vortices in the upper troposphere to the southward displacement of the subtropical South Atlantic anticyclone. On the continent in JJA, the areas with greater rainfall are situated in northwest and southeast SA (SESA) in all simulations, agreeing with the patterns seen in the observations (Fig. 3). In the latter region, much of the rain results from the passage or development of extratropical cyclones and their associated frontal systems, which are more frequent during Austral winter (Gan and Rao 1991; Reboita et al. 2010). In northwestern SA, precipitation is mainly organized by the action of the ITCZ. In both areas, the spatial patterns of rainfall (location of maxima and minima) simulated by NUGEM are closer to TRMM than that simulated by NUGAM, indicating the importance of ocean-atmosphere coupling in the reproduction of observed patterns.

As mentioned above, there is a strong similarity between the spatial patterns of simulated and observed precipitation in Austral winter (Fig. 3). However, the rain rate is overestimated in some regions, especially the western edge of mountainous regions such as the south of Chile. This is a common feature in many models. Mountains block the flow from the west and force upward motion with consequent intense precipitation, i.e. incorrectly simulating the circulation and precipitation patterns associated with elevated topography (Stern and Miyakoda 1995; Cavalcanti et al. 2002). In addition, owing to the small number of direct observations (rain gauges) as well as the poor quality of precipitation estimates via satellite in the Andean region, the validation of the models becomes difficult in this area. From the observational point of view, the analysis of rain in extratropical mountainous regions needs to be improved, so that models can be correctly evaluated. The comparison between models and observations in Figs. 2 and 3 indicates that the increase in horizontal resolution in the coupled models (HiGEM and NUGEM) helps to reduce the rainfall excess simulated by HadGEM over the mountainous Andes region (from $25^{\circ}$ to $10^{\circ} \mathrm{S}$, especially in Austral summer).

Another important factor is that the coupled models simulate precipitation in much of Amazonia quite well compared to observations in the two seasons (Figs. 2, 3), with small systematic errors. This represents a significant improvement compared to other GCMs, such as the MCGA (atmospheric GCM) of CPTEC-COLA (Cavalcanti et al. 2002), ECMWF (Brankovic and Molteni 1997) and NCAR-CCM3 (Hurrel et al. 1998), which show a significant rain deficit over the Amazon region in Austral summer. In general, the atmosphere-only models have higher systematic errors than the coupled models in the Amazon in Austral summer (Fig. 2).

Overall, the coupled models produce spatial precipitation patterns similar to observations (Figs. 2, 3c-e). Increasing horizontal resolution tends to reduce the simulation biases, such as over the center-west Brazil in Austral winter (Fig. 3), or over subtropical and tropical areas of the Andes throughout the year. Moreover, the coupled models, despite their precipitation excess bias, tend to have smaller systematic errors in seasonal fields than the atmosphereonly models. These results indicate that the increase in resolution associated with the ocean-atmosphere coupling, which includes daily SST variations, results in a more realistic simulation of precipitation over SA and the tropical oceans than the low-resolution atmosphere-only models of the HadGEM1 family.

\subsection{Seasonal climatology: surface air temperature}

The spatial distribution of temperature in Austral summer (Fig. 4) and winter (Fig. 5) over the oceans in the atmosphere-only and coupled simulations is similar to observations, while the differences between simulations and observations are larger over the continent. The models simulate a warmer and colder surface air over north-central and southcentral SA, respectively. In the atmosphere-only simulations, the biases are smaller than in the coupled simulations in the northern and southeast-central parts of SA. Over the oceans, the atmosphere-only simulations are slightly warmer than the observations ensemble, including over the Northern Hemisphere ITCZ region. The better performance of the atmosphere-only models in simulating the surface air temperature is consistent with the fact that these simulations are forced with observed SSTs, which act as a direct regulator for the simulation of air temperature.

In both coupled and atmosphere-only simulations, higher temperatures (above $22{ }^{\circ} \mathrm{C}$ ) occur in the latitudinal belt, $5^{\circ} \mathrm{N}-30^{\circ} \mathrm{S}$, in Austral summer (Fig. 4), while such temperatures have a smaller north-south extent, $5^{\circ} \mathrm{N}-20^{\circ} \mathrm{S}$, in Austral winter (Fig. 5). Temperatures below $20^{\circ} \mathrm{C}$ also 

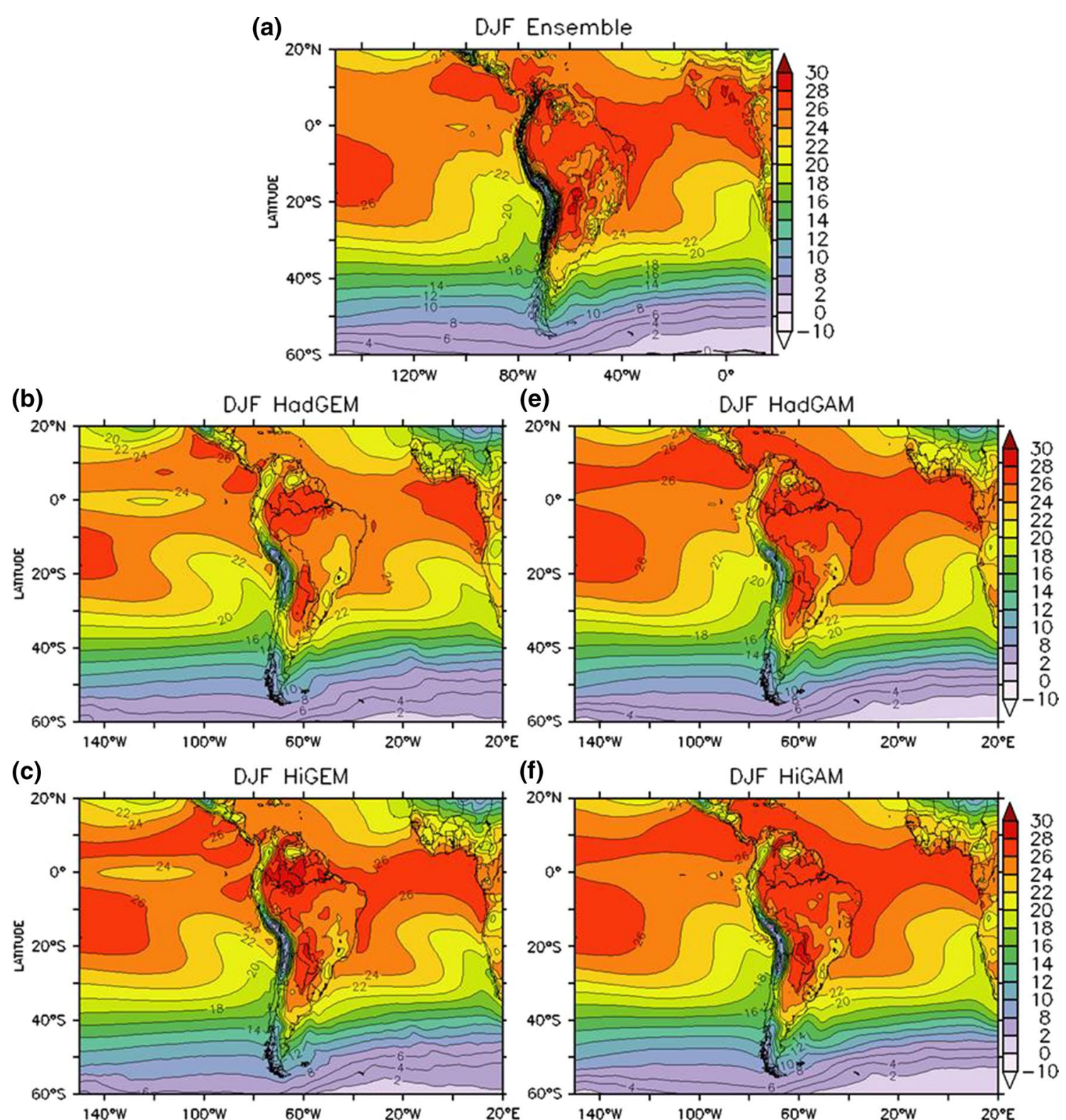

(f)

DJF HiGAM
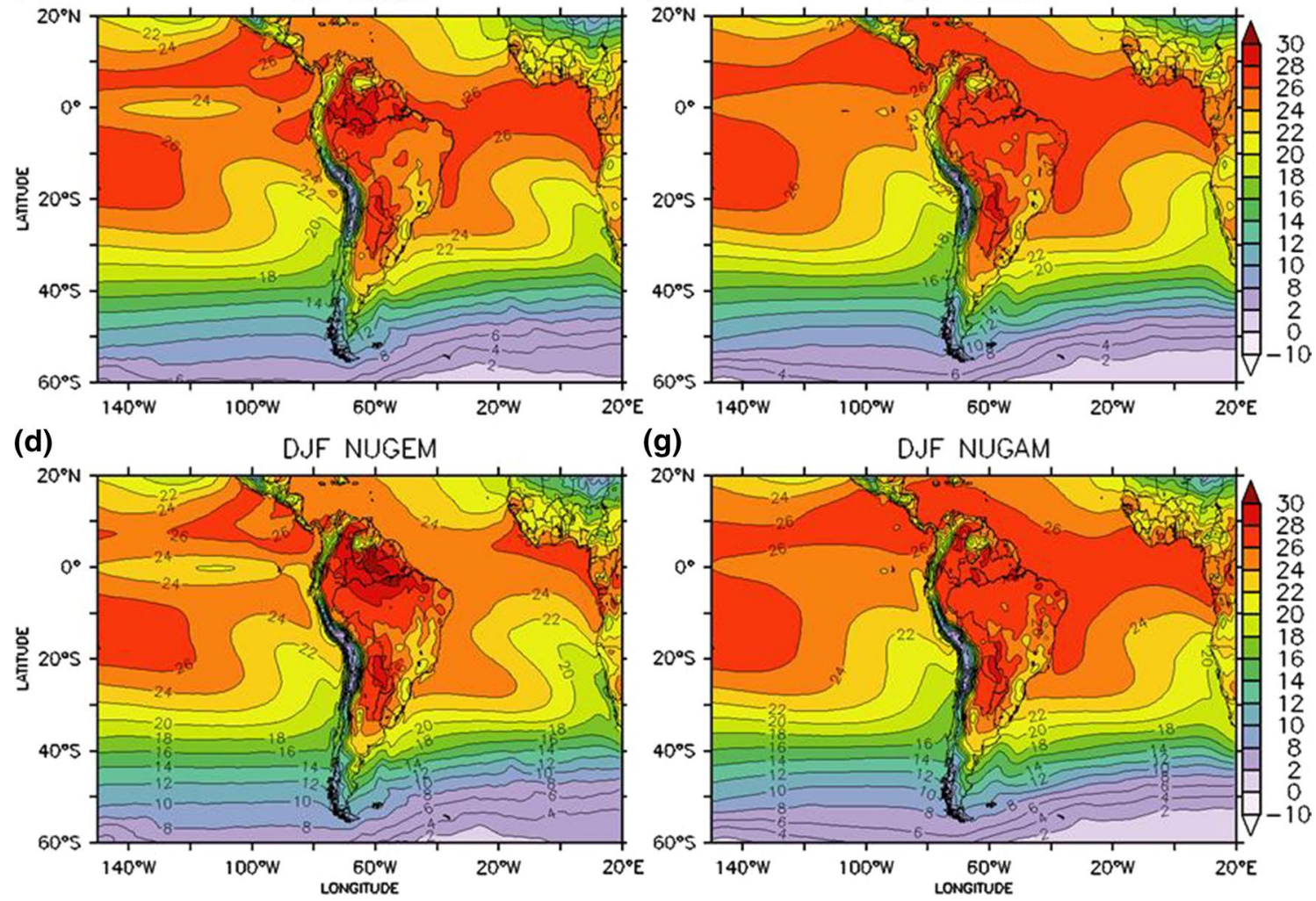

(g)

DJF NUGAM

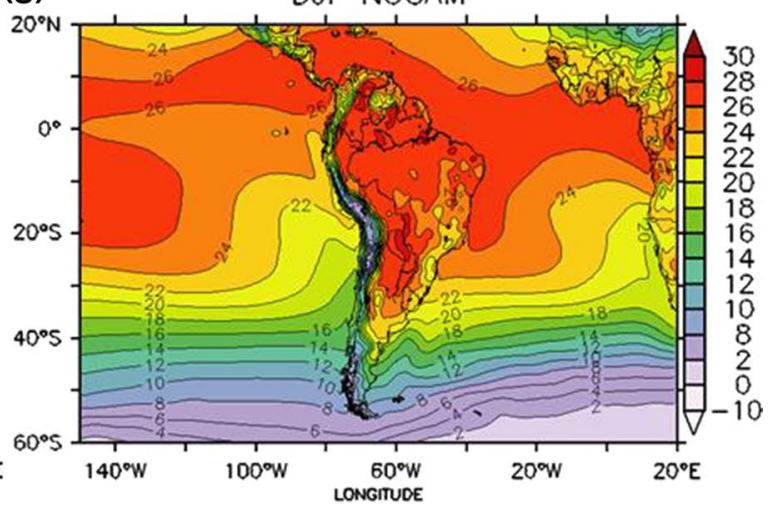

Fig. 4 Seasonal climatology of surface temperature $\left({ }^{\circ} \mathrm{C}\right.$ ) in South America in the summer (DJF) from observations (a), coupled models $\operatorname{HadGEM}(\mathbf{b}), \operatorname{HiGEM}(\mathbf{c})$ and NUGEM (d) and atmospheric models HadGAM (e), HiGAM (f) and NUGAM (g) 


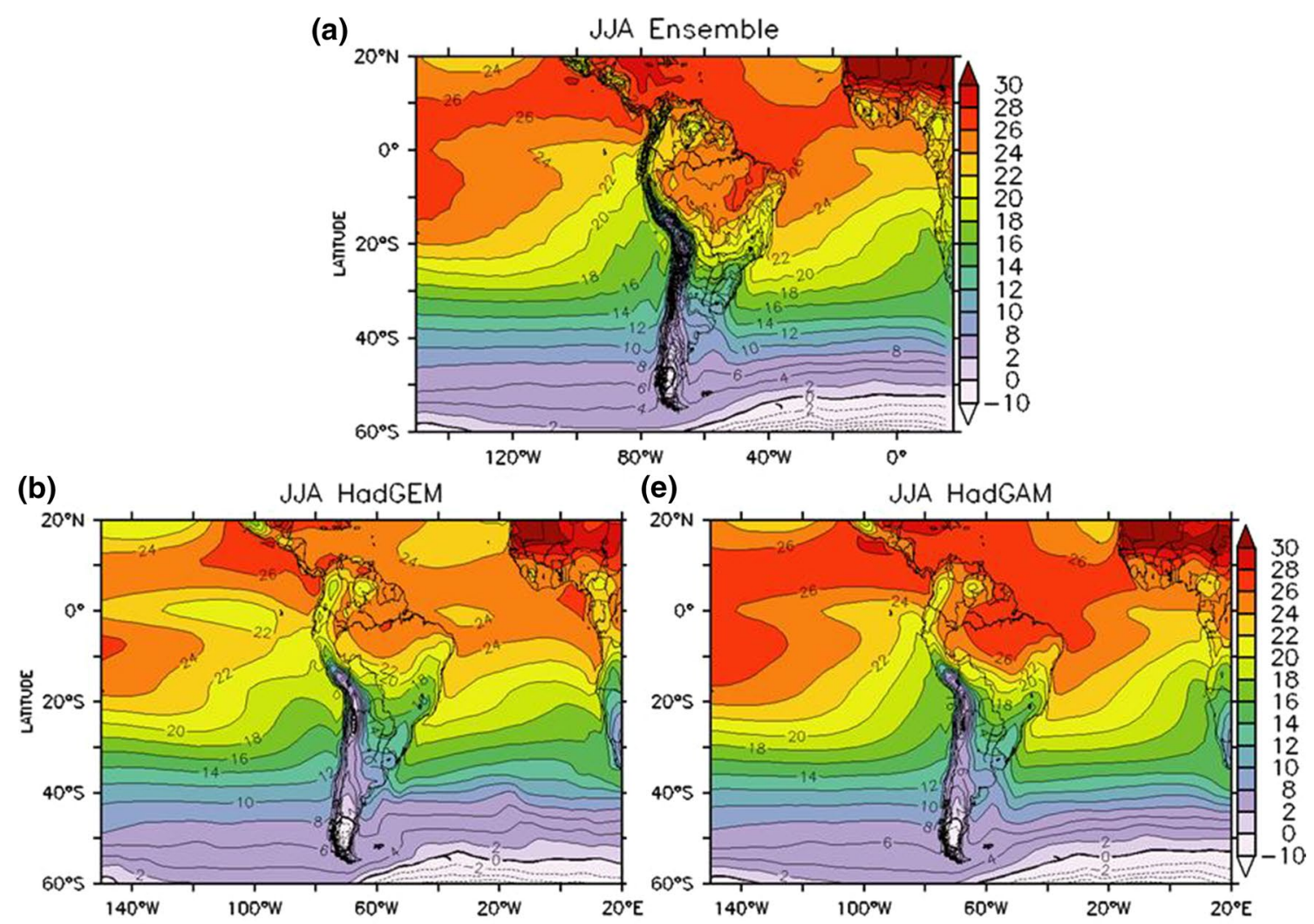

(c)

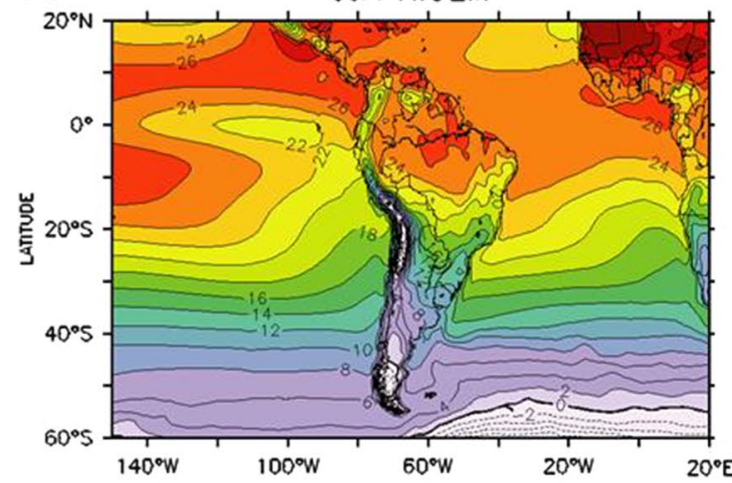

(d)

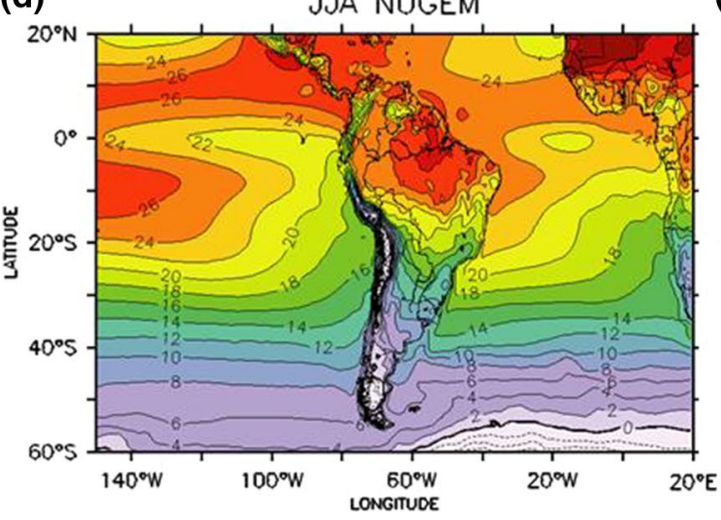

(f)

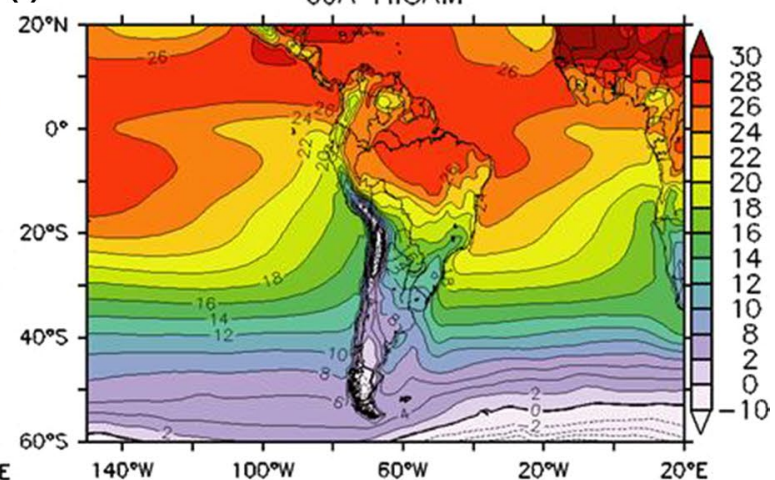

(g)

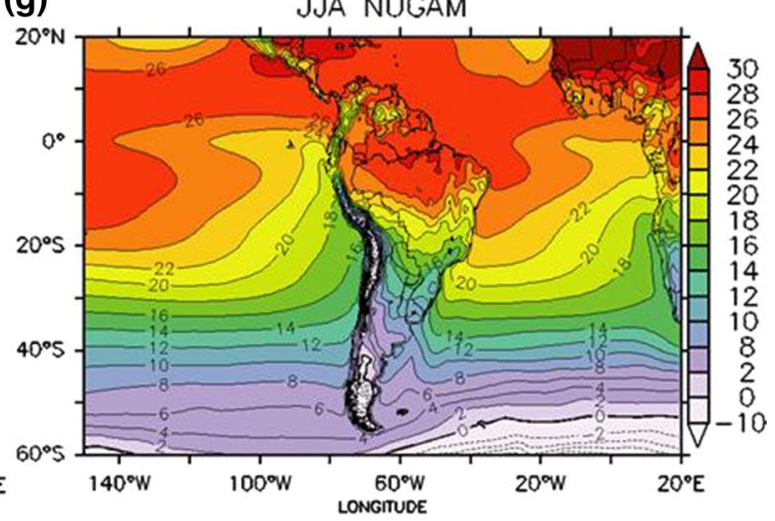

Fig. 5 Seasonal climatology of surface temperature $\left({ }^{\circ} \mathrm{C}\right)$ in South America in the winter (JJA) from observations (a), coupled models HadGEM (b), HiGEM (c) and NUGEM (d) and atmospheric models HadGAM (e), HiGAM (f) and NUGAM (g) 


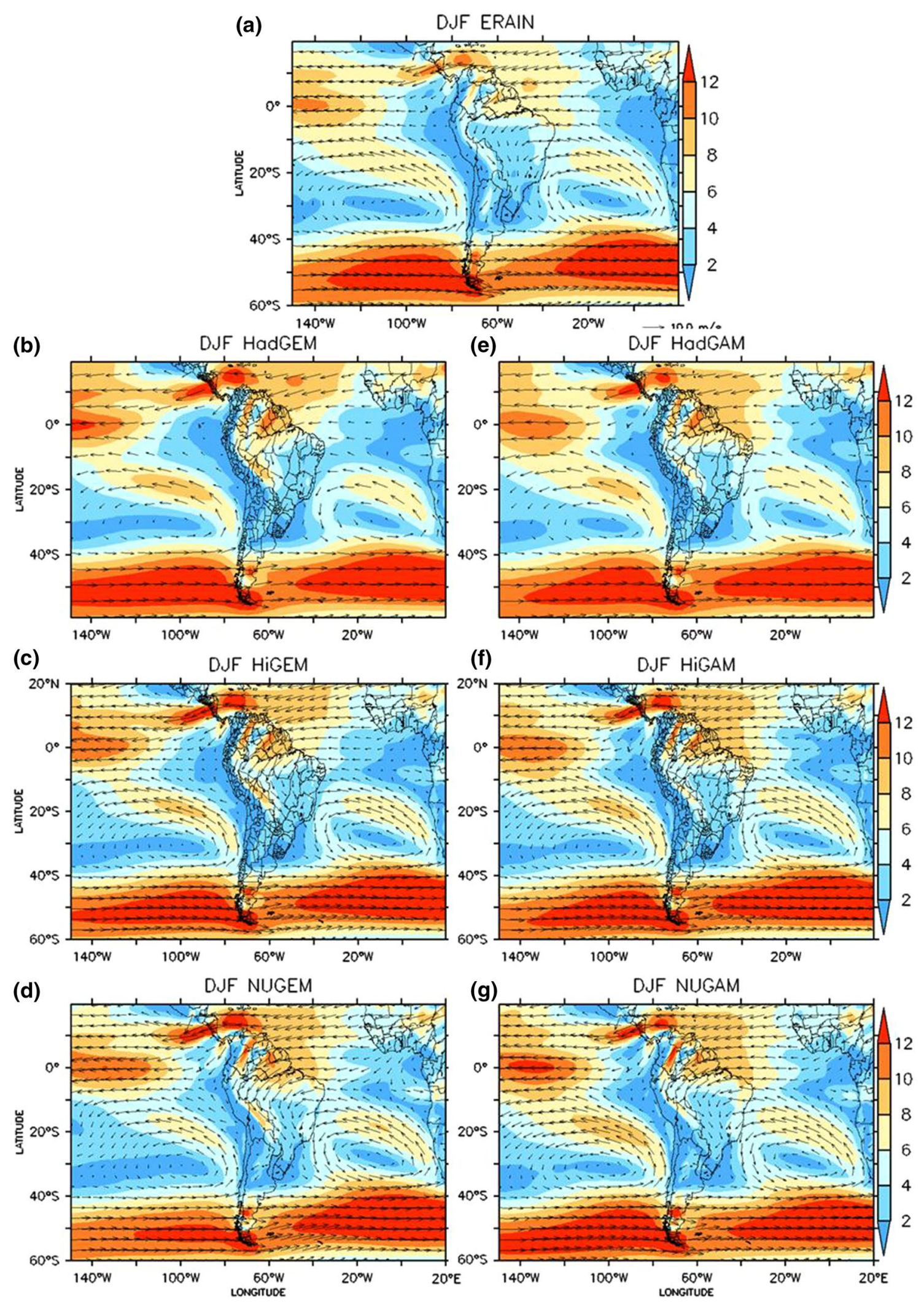

Fig. 6 Seasonal climatology of wind $\left(\mathrm{ms}^{-1}\right)$ at $850 \mathrm{hPa}$ in South America in summer (DJF) from ERAInterim (a), coupled models HadGEM (b), HiGEM (c) and NUGEM (d) and atmosphere-only models HadGAM (e), HiGAM (f) and NUGAM (g) 
occur over the Andes and at higher latitudes (south of $35^{\circ} \mathrm{S}$ in summer and south of $25^{\circ} \mathrm{S}$ in winter) in both atmosphere-only and coupled simulations.

In the Pacific equatorial region (Fig. 4b-d), coupled simulations are colder than the observations ensemble in Austral summer, but HiGEM has the smallest biases (Fig. 4c). In the Atlantic Ocean, HadGEM and NUGEM underestimate surface air temperature compared to the observations ensemble in Austral summer, as they do not simulate temperatures above $26{ }^{\circ} \mathrm{C}$ anywhere in a region that extends all the way to the Brazilian northeast coast. HiGEM is the only model that shows elevated temperatures from the Brazilian east coast to Africa in the equatorial region. In contrast, NUGEM has the smallest temperature biases in the southern part of the Atlantic, where temperatures are below $24{ }^{\circ} \mathrm{C}$. In Austral winter (Fig. 5), the coupled simulations are also colder than observations in the equatorial Pacific and Atlantic oceans. In the equatorial Pacific, the existence of a cold tongue (centered at the equator) elongated toward the west may result from more intense trade winds (see Fig. 7) with the consequent intensification of upwelling in the coupled simulations. Observations show a region on the continent in northeastern SA with temperatures above $26{ }^{\circ} \mathrm{C}$, which in the coupled models is not properly simulated. Only HiGEM and NUGEM simulations show elevated temperatures in this region, although with a much smaller extent than observed. The model with low horizontal resolution (HadGEM), in addition to not simulating this warm region in winter on the continent, is cooler by $2{ }^{\circ} \mathrm{C}$ (or more) in the equatorial Pacific (Fig. 5b).

Blázquez and Nuñez (2012) showed that in the summer (DJF), fall (MAM), and spring (SON) the high-resolution global atmosphere-only model of the Japanese Meteorological Agency (JMA/MRI) underestimates temperature by up to $4{ }^{\circ} \mathrm{C}$ in eastern Argentina, western Uruguay, southern Chile and in the Tropics. In comparison, the errors in both the coupled and the atmosphere-only simulations analyzed here are much smaller (bias of less than $+0.5{ }^{\circ} \mathrm{C}$ in these regions) than those obtained in Blázquez and Nuñez (2012). It has to be noted that this JMA/MRI model used a grid spacing of $20 \mathrm{~km}$ (TL959), i.e. higher than the horizontal resolution of the models discussed here, and still presents significant errors in the simulation of seasonal temperature. This indicates that in addition to increasing the resolution of climate models, the physical parameterizations of these models are also of great importance in reducing simulation errors over SA.

Overall, increasing horizontal resolution tends to reduce errors in the simulation of surface air temperature, naturally over the oceans in atmosphere-only models, which are forced by observed SST. The largest systematic errors occur over the oceans and northern SA. The equatorial region of the Pacific Ocean is also identified in the seasonal analysis of precipitation (Figs. 2,3) as having a break in the ITCZ. The coupled models also have relatively large errors in air temperature over the ocean, which indicates the need for improvements in the simulation of SST that has a direct impact on air temperature over the ocean due to the turbulent processes at the air-sea interface.

\subsection{Seasonal climatology: circulation at low and upper levels}

At low levels $(850 \mathrm{hPa})$, the main circulation patterns during Austral summer (Fig. 6) and winter (Fig. 7) in ERAIN show the subtropical high over Pacific and Atlantic Oceans (centered in $30^{\circ} \mathrm{S}$ in summer and $25^{\circ} \mathrm{S}$ in winter); the southeasterly trade winds over tropical Atlantic and Pacific Oceans that intensify from summer to winter; the westerly flow crossing over the Pacific and Atlantic Oceans at high latitudes (south of $40^{\circ} \mathrm{S}$ ), which intensify from summer to winter; and the maximum of northwest wind speed east of the Andes, known as east Andes Low Level Jet (LLJ). All these systems are properly simulated by both coupled and atmosphere-only models. In some areas, as in the equatorial Atlantic near the northern coast of SA and the high latitudes westerly flow (south of $40^{\circ} \mathrm{S}$ ), the wind speed errors are smaller in NUGEM.

The maximum northwest wind speed in east of the Andes LLJ is more intense in summer (Fig. 6) than winter (Fig. 7) in ERAIN. In this reanalysis, the LLJ undergoes a meridional displacement between winter and summer, being centered further north in summer (northern Bolivia) and further south in winter (northern Paraguay). The coupled and atmosphere-only models correctly simulate these characteristics observed in the LLJ in ERAIN. In winter, the winds at $850 \mathrm{hPa}$ on the northeast coast of SA are stronger in atmosphere-only models than in the coupled models and ERAIN (Fig. 7). This pattern in the atmosphere-only models can explain the greater intensity of the ITCZ in this area (Fig. 3), since the deceleration of the trade winds induces greater convergence and increased rainfall.

Figure 8 presents a vertical cross section of the wind speed at $17.5^{\circ} \mathrm{S}$ latitude in summer, the season during which the LLJ is quite typical (Marengo et al. 2003). In the atmospheric simulations, in both the intensity of the core of the LLJ as well as the vertical level of its top speed, there is virtually no change with increased horizontal resolution of the models (Fig. 8). In these three simulations, the core of the LLJ is located at higher pressure levels $(\sim 700 \mathrm{hPa}$ in NUGAM and $725 \mathrm{hPa}$ in HadGAM) than in ERAIN $(\sim 850 \mathrm{hPa})$. However, the maximum speed of the LLJ is closer to that of ERAIN. The coupled models have a different behavior in relation to the low level jet. With the increase of the horizontal resolution in these models, the LLJ intensifies as shown in Fig. 8. Furthermore, with the 

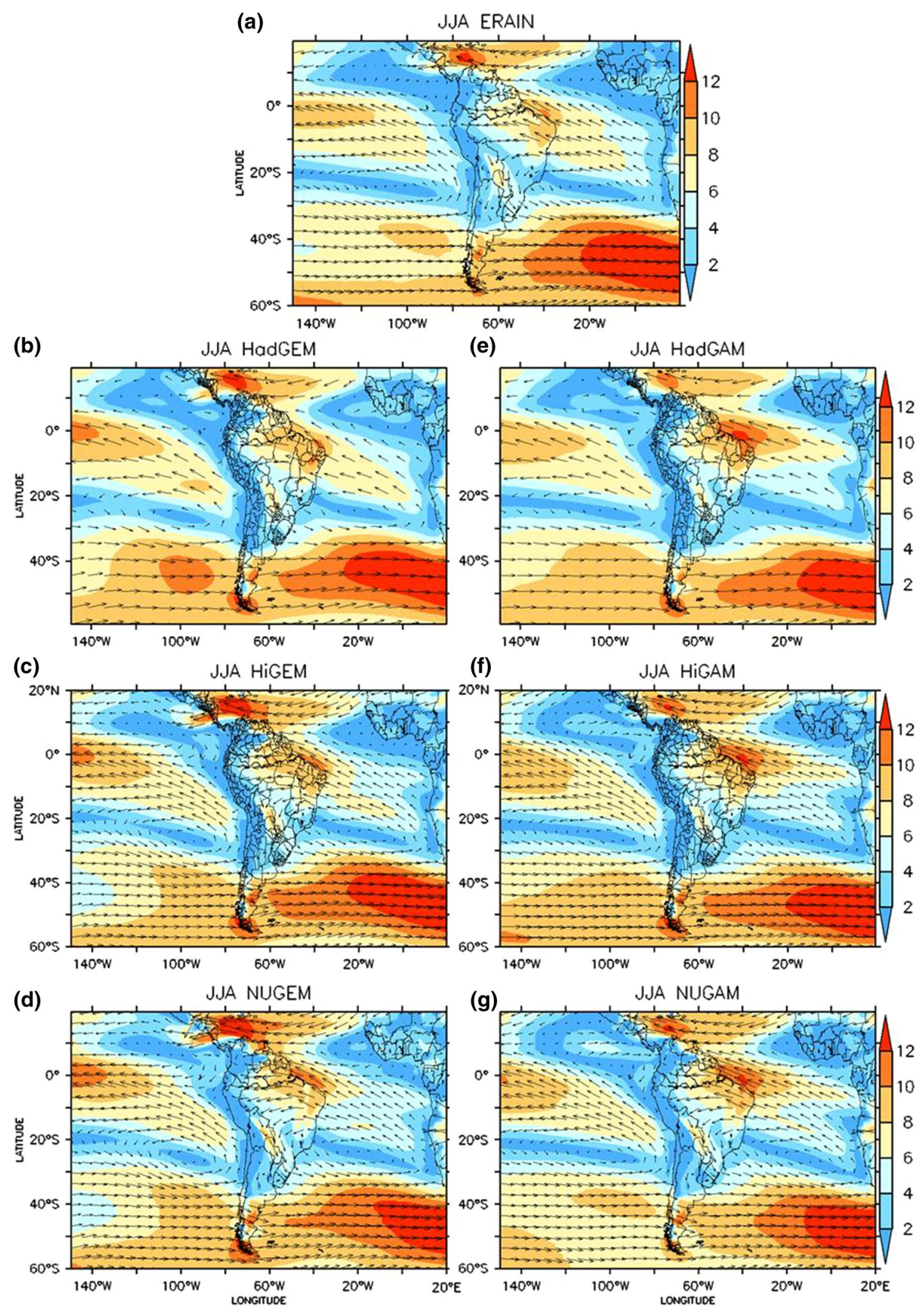

Fig. 7 Seasonal climatology of wind $\left(\mathrm{ms}^{-1}\right)$ at $850 \mathrm{hPa}$ in South America in winter (JJA) from ERAInterim (a), coupled models HadGEM (b), HiGEM (c) and NUGEM (d) and atmosphere-only models HadGAM (e), HiGAM (f) and NUGAM (g) 

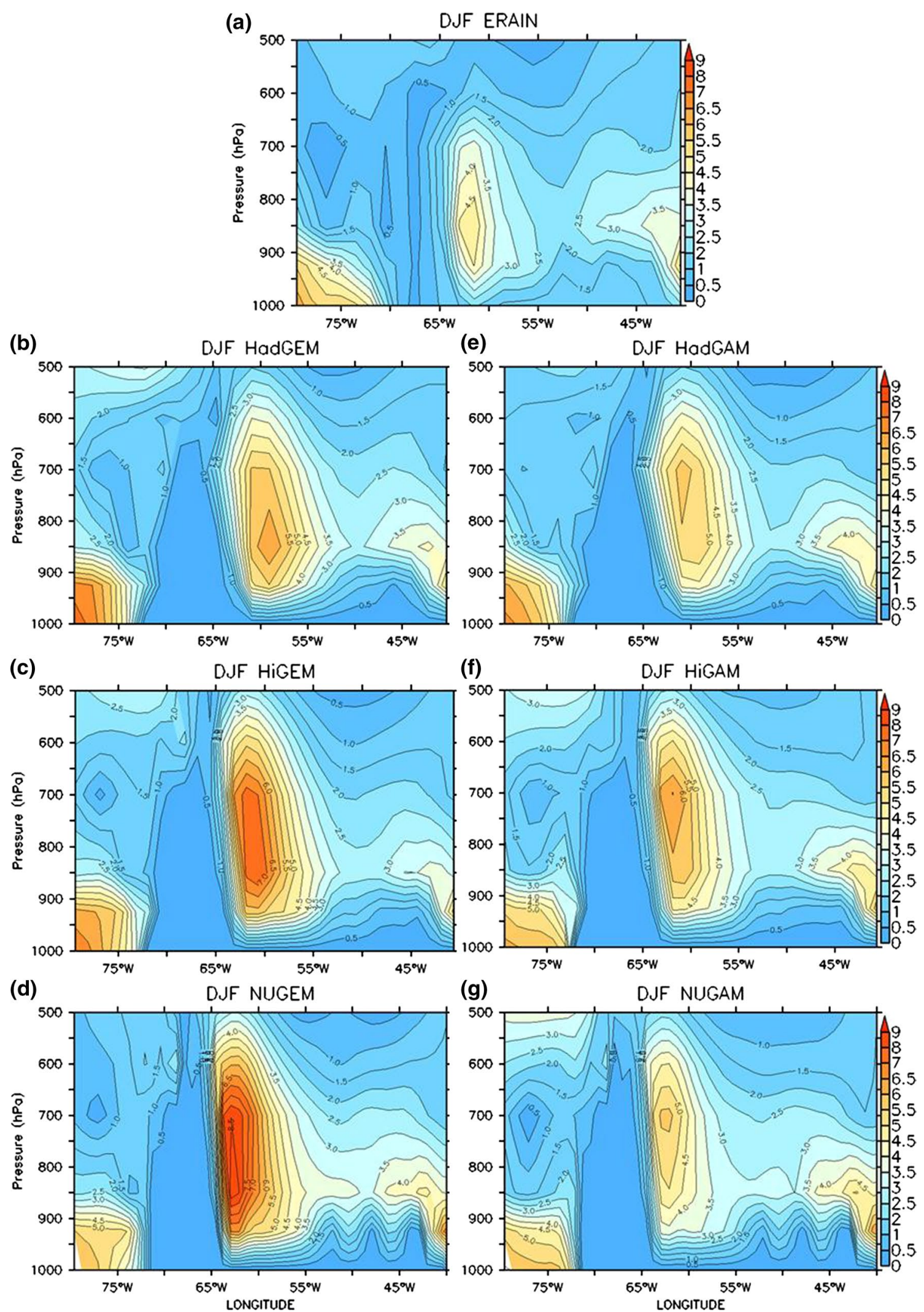

Fig. 8 Vertical profile of wind $\left(\mathrm{ms}^{-1}\right)$ at $17.5^{\circ} \mathrm{S}$ latitude in South America in summer (DJF) from ERAInterim (a), coupled models HadGEM (b), HiGEM (c) and NUGEM (d) and atmosphere-only models HadGAM (e), HiGAM (f) and NUGAM (g) 


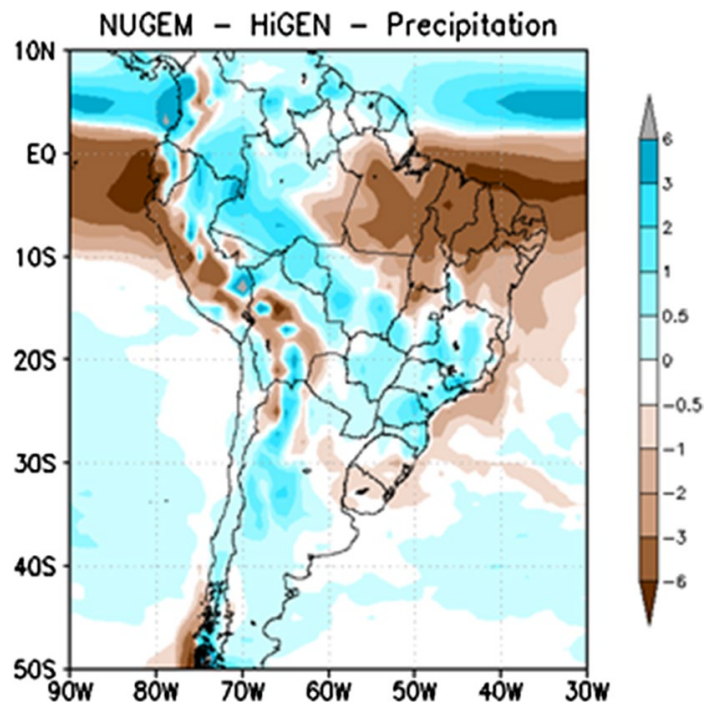

Fig. 9 Difference in summer (DJF) precipitation between NUGEM and HiGEM

increased resolution the core of the LLJ is moved west, closer to the Andes, i.e., the jet is centered at $\sim 61^{\circ} \mathrm{W}$ in HadGEM and $\sim 63^{\circ} \mathrm{W}$ in NUGEM. This indicates a direct impact of the more realistic topography used by NUGEM, and in this simulation the position of the LLJ is closer to that of ERAIN. On the other hand, with the increase in resolution, the core of the LLJ occurs at higher pressure levels $(\sim 8.5 \mathrm{~m} / \mathrm{s}$ at $800 \mathrm{hPa}$ in NUGEM) and is more intense than in ERAIN $(\sim 4.5 \mathrm{~m} / \mathrm{s}$ at $850 \mathrm{hPa})$. Note that caution is needed when analysing the LLJ intensity since, in the region of LLJ, there is no direct observation of air superior (soundings) to be assimilated by ERA-Interim, which may provide a weak jet in the reanalysis. For example, for the period 15 January-14 February 2003 during SALJJEX the special observations of air superior were assimilated by Herdies et al. (2007) in high-resolution global reanalysis systems (with $1^{\circ}$ of horizontal grid). For example, they obtained stronger winds in the LLJ region (mean wind speeds greater $8 \mathrm{~m} \mathrm{~s}^{-1}$ ) and a narrower LLJ core closer to the Andes after assimilation of upper air SALLJEX observations.

Only in coupled simulations does the increase of resolution change significantly the LLJ intensity (Fig. 8) and spatial pattern of precipitation during summer (Fig. 2). Therefore, the more intense LLJ in NUGEM is a result of the association between coupling and high resolution. For example, the difference between NUGEM $(60 \mathrm{~km})$ and HiGEM $(90 \mathrm{~km})$ shows more precipitation in part of SESA, southeast Brazil and western Amazon during summer (Fig. 9). This is explained by a better representation of the SACZ in NUGEM (Fig. 3e) and the intensification of moisture transport from north to south-southeast SA.

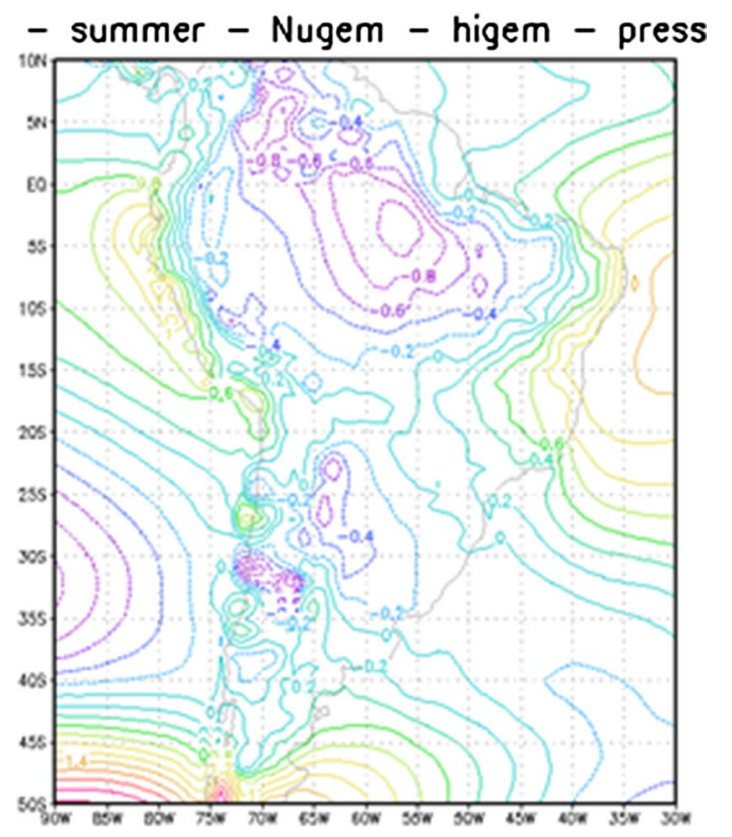

Fig. 10 Difference summer (DJF) sea level pressure between NUGEM and HiGEM

The difference in sea level pressure between NUGEM and HiGEM (Fig. 10) shows two important features: (a) a negative anomaly of pressure over SESA (centered $\sim 30^{\circ} \mathrm{S}$ ) and surrounding areas, which may indicate more intense (or frequent) baroclinic systems, which, according Sugahara et al. (1994), act to intensify the east Andes LLJ; (b) a more intense subtropical high in south Atlantic ocean, another feature in NUGEM that also contributes to intensify this LLJ (Misra et al. 2003; Cuadra and da Rocha 2006). Besides the east Andes LLJ, Fig. 8 depicts that simulations adequately reproduce the speed maxima in the lowermost troposphere (between 1000 and $900 \mathrm{hPa}$ ) associated with the subtropical anticyclones in the Pacific (west of $75^{\circ} \mathrm{W}$ ) and Atlantic (east of $45^{\circ} \mathrm{W}$ ).

ERAIN shows in Fig. 11 the circulation at $200 \mathrm{hPa}$ over SA, where the two characteristic systems that are prominent during the summer are the $\mathrm{BH}$ (centered at $\sim 22^{\circ} \mathrm{S}-60^{\circ} \mathrm{W}$ ) and the trough over northeastern Brazil (trough axis at $\sim 20^{\circ} \mathrm{W}$ ). The coupled and atmosphere-only models simulate these two systems similar to ERAIN in position and intensity. The BH is a quasi-stationary anticyclone which in ERAIN is centered at $\sim 20^{\circ} \mathrm{S}, 70^{\circ} \mathrm{W}$. Although the simulations correctly represent the position of the $\mathrm{BH}$, it worth noting that this system is simulated closer to ERAIN in NUGEM than in other simulations. The small error in positioning the $\mathrm{BH}$ in the simulations can be explained by the realistic representation of rain in the Amazon since numerical studies indicate that this system would be a response to the heat source associated with convection 

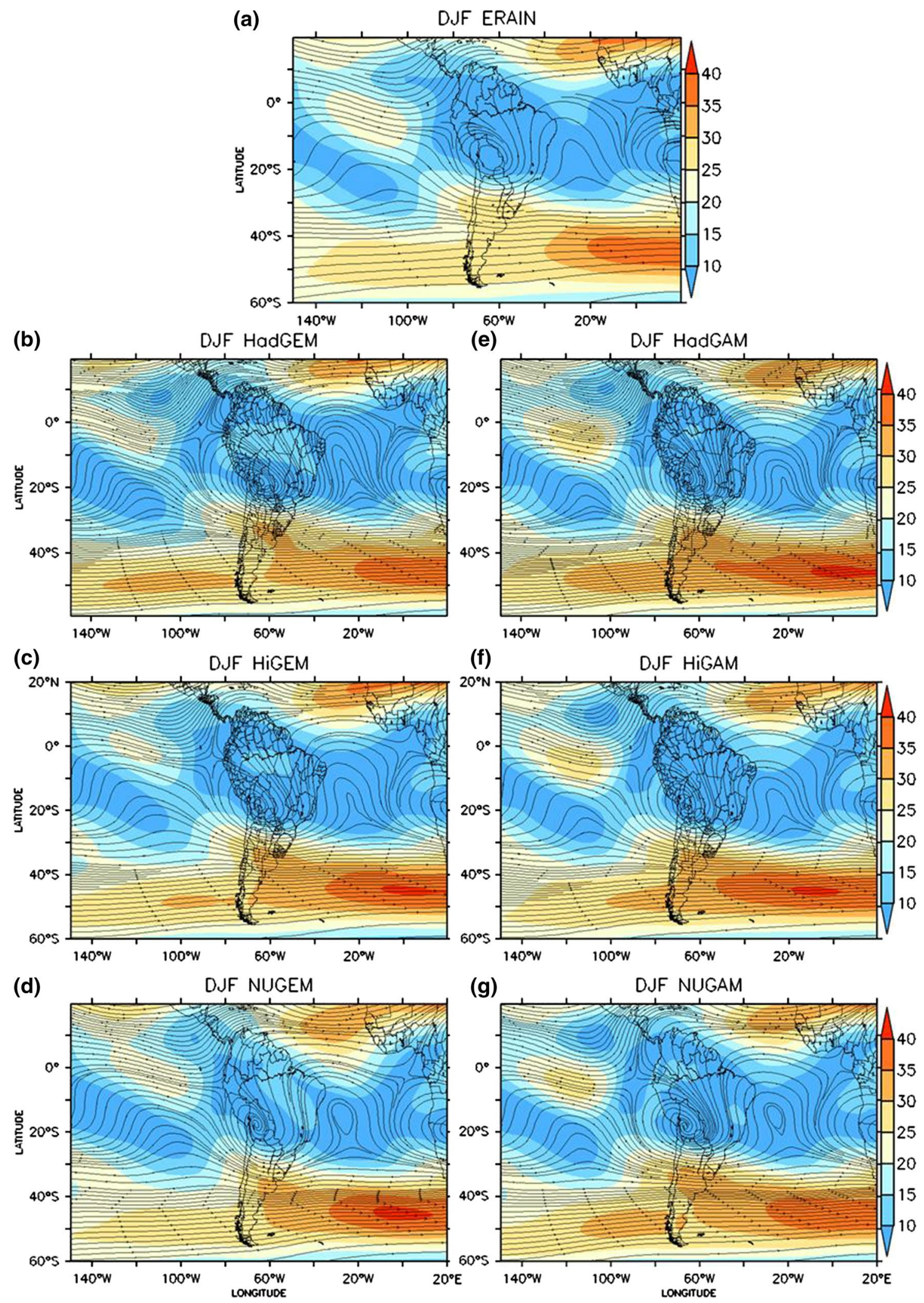

Fig. 11 Seasonal climatology of wind at $200 \mathrm{hPa}$ in South America in summer (DJF) from ERAInterim (a), coupled models HadGEM (b), HiGEM (c) and NUGEM (d) and atmosphere-only models HadGAM (e), HiGAM (f) and NUGAM (g) 
in this basin (Gandu and Geisler 1991; Lenters and Cook 1997). The trough over northeastern Brazil is also represented in the six simulations, although the coupled as well as the atmosphere-only models locate it east of its position in ERAIN. The models show a pattern similar to ERAIN in the simulation of the speed maximum in the westerly flow over the southeast sector of the South Atlantic Ocean (east of $\sim 30-20^{\circ} \mathrm{W}$ and centered on $45^{\circ} \mathrm{S}$ latitude) and the weakening of the subtropical jet over the south Pacific and South America (Fig. 11). NUGEM simulates both factors of the $200 \mathrm{hPa}$ flow at mid-latitudes more closely to ERAIN.

\subsection{Regional climatology: annual cycle and biases}

The annual cycles of precipitation and temperature for five subdomains of South America are shown in Figs. 12 and 13. In region AMZ (Fig. 12a), the rainy season in the observation occurs from December to March (maximum of $10 \mathrm{~mm} \mathrm{day}{ }^{-1}$ ) while the dry season occurs from June to August (minimum of $1 \mathrm{~mm}^{\mathrm{day}}{ }^{-1}$ ). All simulations correctly represent the observed phase of the annual cycle of rain in the region, which is reflected in high correlation coefficient values (between 0.98 and 0.99 ) as shown in Fig. 12b. However, the simulations are wetter over a large part of the year (mainly from January to March) than the ensemble, except NUGEM in some months of the year. The refinement of the grid in coupled models (NUGEM) contributed to a smaller annual bias $\left(0.2 \mathrm{~mm} \mathrm{day}^{-1}\right)$, while for the atmosphere-only models (NUGAM) the bias increases with the increase in resolution $\left(1.4 \mathrm{~mm} \mathrm{day}^{-1}\right)$. Figure $12 \mathrm{~b}$ also shows that the simulated standard deviation is close to the ensemble, especially in NUGEM and HiGEM. This would indicate the importance of ocean-atmosphere coupling and grid refinement for realistic simulations of rain over AMZ.

As pointed out by Custodio et al. (2012), the slightly altered version of the coupled and atmosphere-only models of the HadGEM family did not have the dry bias in the region of the Amazon basin that is pointed to as a common error in many climate models in the region (Cavalcanti et al. 2002; Li et al. 2002; Marengo et al. 2003; Seth and Rojas 2003; Seth et al. 2007; Ma et al. 2011). This error is usually attributed to the smoothing of the Andes in global climate models. For the models of the HadGEM family, although versions differ from one another in their configurations, these differences did not alter significantly the representation of the annual cycle of precipitation in AMZ.

The observations show that the rainy season in NDE is concentrated in the months from January to April, with a peak in March, due to the shift to the south of the ITCZ (Fig. 12c). In the following months the rain decreases abruptly, reaching minimum values $\left(1 \mathrm{~mm} \mathrm{day}^{-1}\right)$ in August-September (Fig. 12c). The coupled and atmosphere-only models are in phase with the observed annual cycle of rain with correlation greater than 0.95 (Fig. 12d), but there are some differences in intensity. Among coupled models (Fig. 12c), those with lower resolution (HadGEM and HiGEM) present the highest relative biases (47 and $37 \%$, respectively) for the region since they are wetter (drier) than the ensemble during the rainy (dry) season. The larger amplitude of the annual rain cycle in these simulations is reflected in the larger values of the standard deviation (Fig. 12d). NUGEM remains drier than the observations throughout the year, and among the coupled simulations provides the lowest relative bias $(-25 \%)$ and standard deviation similar to that of observed dataset. In the NDE region, the biases of precipitation in the atmosphere-only models $(13 \%$ in HadGAM, $+3 \%$ in HiGAM, and $5 \%$ in NUGAM) are smaller than in the the coupled models. The best performance of atmosphere-only models in simulating the annual cycle of precipitation in the NDE is directly related to incorrect positioning of the ITCZ over northern SA in HadGEM and HiGEM (see Fig. 3c, d). The increase of the horizontal resolution in the coupled models lessens the overestimation of rainfall in NDE while correctly positioning the ITCZ (see Fig. 3e).

During the rainy season the wet bias in NDE occurs in most simulations (atmospheric and coupled) indicating little association with the SST. Possibly these errors are related to the local scale physical processes that are not being correctly resolved in the models of the HadGEM family such as, for example, parameterization of convection. By comparing our results with those of Custodio et al. (2012), it can be seen that the changes between the two coupled versions of the HadGEM family do not present a clear trend since in the rainy and dry seasons the bias decreases and increases, respectively, in the version used by Custodio et al. (2012).

In the observations, the rainy and dry seasons occur from June to August and from October to April, respectively, in the SESA region (Fig. 12e). This pattern is correctly simulated by the coupled and atmosphere-only models, although they overestimate the rainfall rate throughout most of the year. In SESA only the coupled model with lowest resolution (HadGEM) remains drier than the observation from January to April. For annual rainfall, the relative biases in SESA range from $+20 \%$ in HiGEM and HiGAM to values close to zero in HadGEM and HiGAM, in other words, values always less than $0.85 \mathrm{~mm} \mathrm{day}^{-1}$. In this region increasing the resolution increases the rainfall rate and the relative bias. However, in all simulations the biases are much lower than previously reported for other global models (Seth et al. 2010; Blázquez and Nuñez 2012) and regional models (da Rocha et al. 2014) in a similar region. Compared to Custodio et al. (2012), the version assessed here does not change the representation of the annual cycle of precipitation in 
Fig. 12 Annual cycle of precipitation $\left(\mathrm{mm} \mathrm{day}^{-1}\right)$ (left column) and Taylor diagram (right column) for coupled

(HadGEM, HiGEM and

NUGEM) and atmosphere-only simulations (HadGAM, HiGAM and NUGAM) and observations ensemble
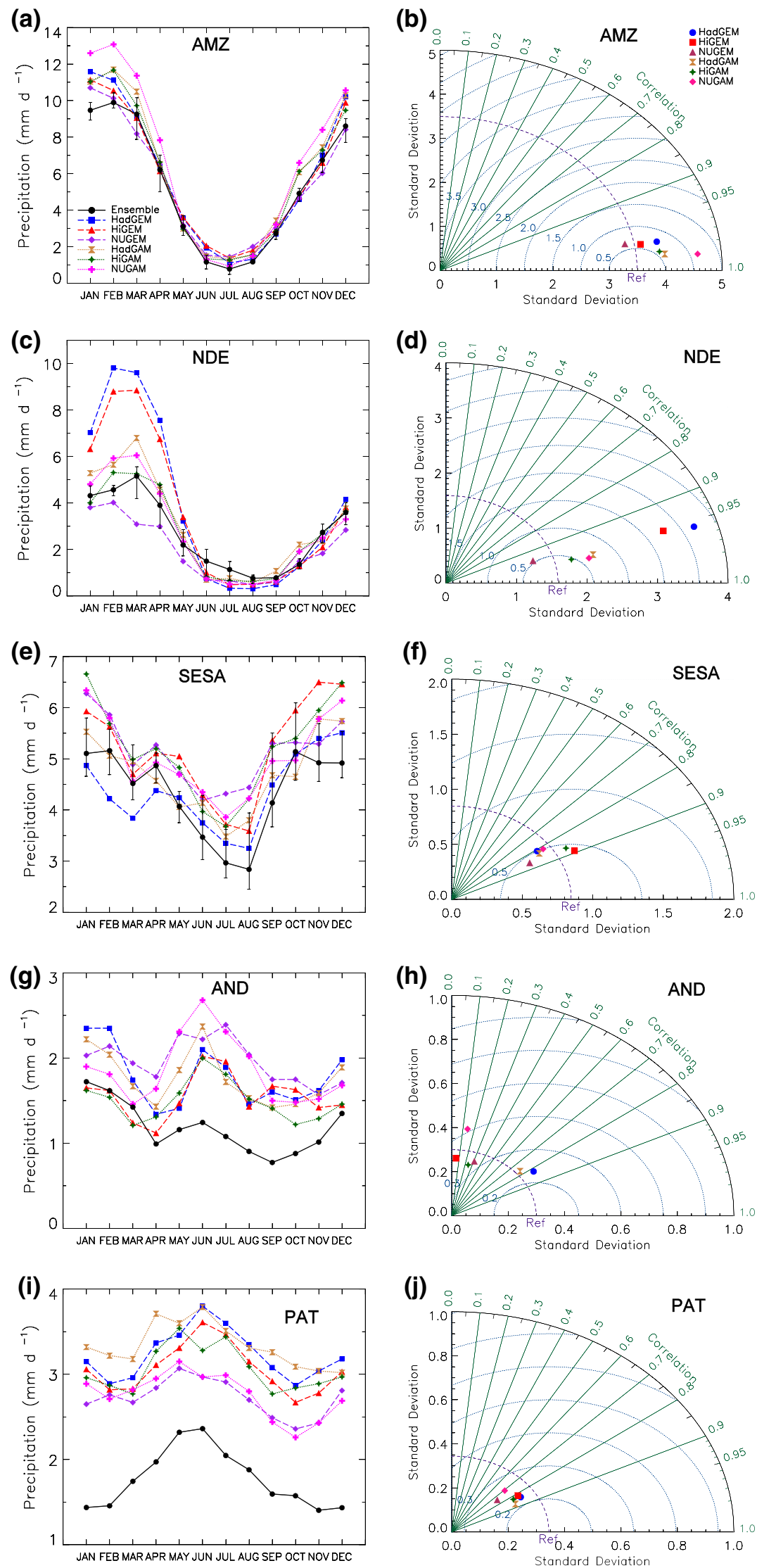
Fig. 13 As in Fig. 12, albeit for surface air temperature
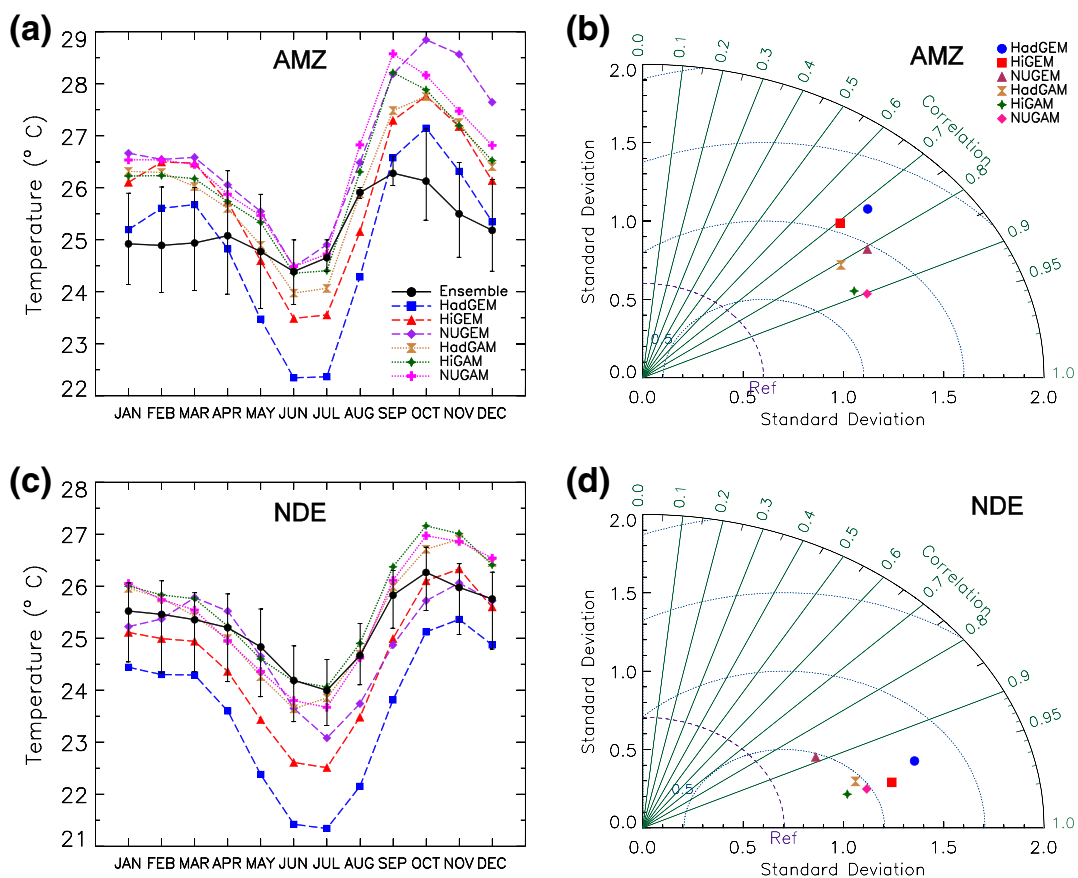

(d)
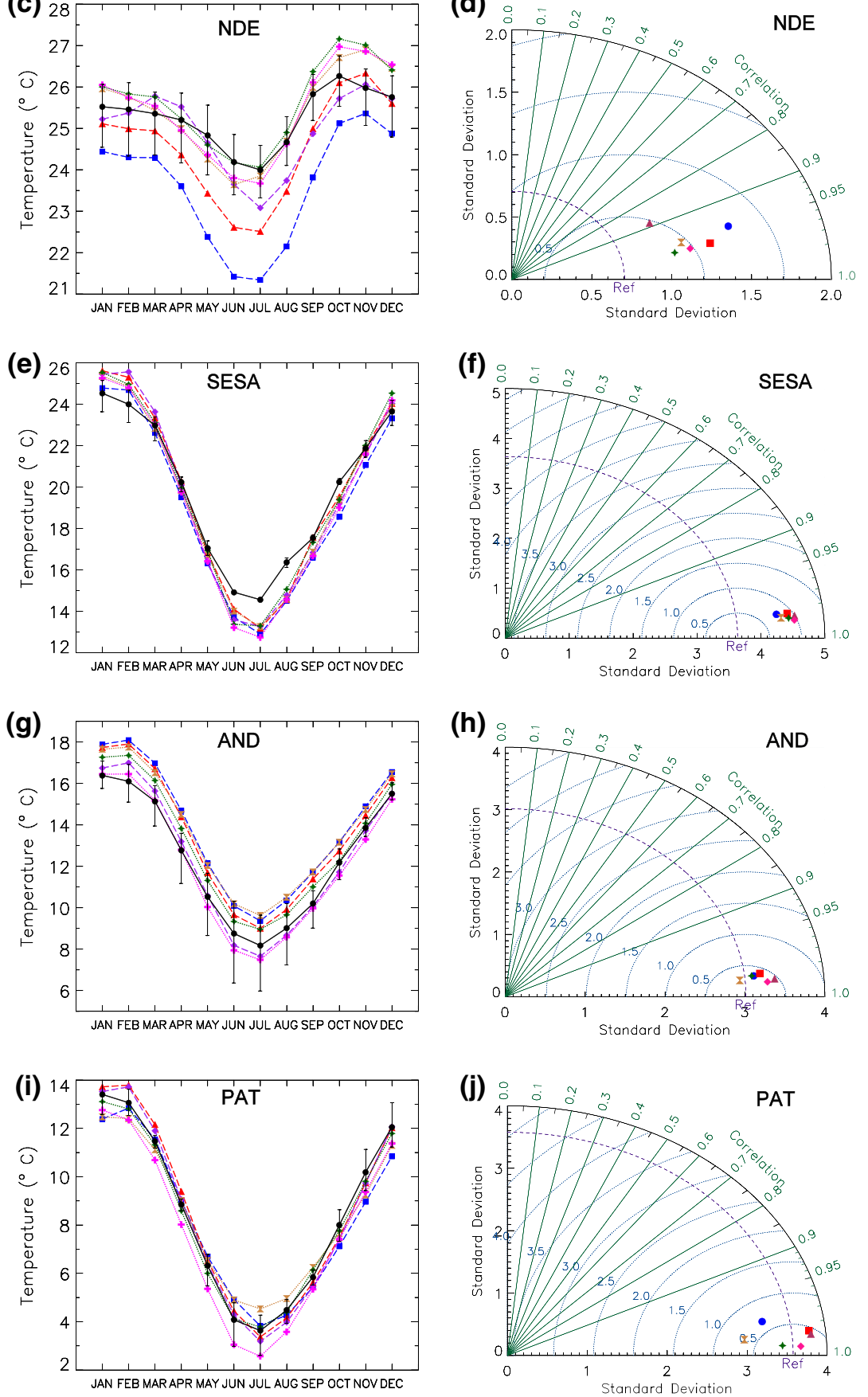
the SESA. In addition, these results represent an improvement compared to the nine coupled models of the CMIP3 project (Seth et al. 2010) and some of the CMPI5 models, which underestimate the spring rainfall by $50 \%$ (da Rocha et al. 2014). Together with the small annual bias in all simulations both the phase and amplitude of the annual precipitation cycle is similar to the observed, as indicated by the high correlation (between $\sim 0.8$ and 0.9 ) and similar standard deviations (Fig. 12f). By comparison, in SESA the atmosphere-only, as well as the coupled simulations, represent a great improvement over the CMIP3 models, which are very dry (annual bias $\sim-3 \mathrm{~mm} \mathrm{day}^{-1}$ ) during the winter and do not simulate the observed phase of the annual cycle of precipitation, principally the peak rainfall in April.

In regions AND (Fig. 12g) and PAT (Fig. 12i), the coupled as well as the atmosphere-only models, although in phase, are wetter than the observation throughout the year. This bias was identified in seasonal fields (Figs. 2, 3), in view of the fact that these areas are in the southern part of the Andes where all simulations overestimate the rain. In these two regions, the monthly rainfall is small and there is not much difference between rainfall throughout the year in the observations, while the models simulate an annual cycle with greater amplitude, implying higher simulation errors. In the AND subdomain (Fig. 12g), almost all of which is located over the Andes, the observed amplitude of the annual precipitation cycle is small $\left(\approx 1.0 \mathrm{~mm} \mathrm{day}^{-1}\right)$. With the increase of the horizontal resolution, the simulated rain intensity increases and therefore the bias as well, which is greater in NUGEM $(+67 \%)$ and NUGAM $(+58 \%)$ than in HiGEM $(+32 \%)$ and HiGAM $(+27 \%)$ with HadGEM providing intermediate values. In this region the correlation for the annual cycle is low $(<0.4)$ in most simulations, except in HadGEM and HadGAM (Fig. 13h). In the higher resolution models (NUGEM and NUGAM), the increase in RMSE (Fig. 12h) indicates a bigger difference between the simulated and observed maxima and minima. In PAT (Fig. 12i), rain in the observation increases in the months of May and June, which is not properly represented in all simulations. Among the coupled models, only NUGEM presents heavier rain in May, while HadGEM and HiGEM simulate only a maximum in June. For the atmosphere-only models, the peaks observed in May-June are not simulated correctly, and only NUGAM simulates maximum rainfall between April and June. With increased resolution the simulations in PAT have an annual rainfall cycle closer to the ensemble, both in coupled and in atmosphere-only models (Fig. 12i). The correlation for the annual cycle is high in the PAT region $(\sim 0.8)$ and, in all simulations, the amplitude of the annual cycle is slightly lower than observed (Fig. 12j). Furthermore, the diagram shows that all simulations have standard deviation values close to the observations and small RMSE (Fig. 12j).
The annual cycles of temperature for the subdomains and their Taylor diagrams are shown in Fig. 13. Among the regions analyzed, the smallest observed annual range of temperature occurs in AMZ (Fig. 13a), where the temperature remains close to $25{ }^{\circ} \mathrm{C}$, with an increase of at most $1{ }^{\circ} \mathrm{C}$ beginning in August. In AMZ, comparison with observations shows great discrepancies in the maximum and the minimum values, with differences of up to $1{ }^{\circ} \mathrm{C}$. Both coupled as well as atmosphere-only models simulate the semi-annual cycle, with two periods of maximum temperature-from September to November and from January to February. This feature does not occur in the annual cycle of precipitation as discussed above. Among the coupled and atmosphere-only models, except for the months from June to July, the models with resolutions of 135 and $90 \mathrm{~km}$ have the smallest systematic errors in relation to the observation. The increased horizontal resolution in AMZ increases the bias of the coupled and atmospheric simulations, i.e. $-0.3{ }^{\circ} \mathrm{C}\left(+0.8{ }^{\circ} \mathrm{C}\right)$ in HadGEM (HadGAM) to $+1.5{ }^{\circ} \mathrm{C}\left(+1.3{ }^{\circ} \mathrm{C}\right)$ in NUGEM (NUGAM). The atmospheric simulations and NUGEM have high correlations (between 0.8 and 0.9) for the annual cycle of temperature, while HadGEM and HiGEM have a slightly lower correlation $(\sim 0.7)$. The larger amplitude of the annual temperature cycle in the simulations implies higher standard deviations and RMSE in the AMZ (Fig. 13b). The larger positive bias of higher resolution horizontal models in representing the annual temperature cycle indicates that the resolution is not the only factor to reduce the temperature simulation errors in the AMZ.

The observed temperature annual cycle in the ensemble for the NDE region (Fig. 13b) locates the warmest period from September to March and the coldest from May to August. The coupled and atmosphere-only models correctly represent these periods. In the NDE, the temperature bias of the atmosphere-only models is lower from January to September, while it is lower in the coupled models from October to December. Increased horizontal resolution reduces the cold bias in the coupled simulations from $-1.7{ }^{\circ} \mathrm{C}$ in HiGEM to $-0.3{ }^{\circ} \mathrm{C}$ in NUGEM. In atmosphereonly simulations, the bias for annual temperature remains practically constant with increasing resolution ( 0.2 and $0.1^{\circ} \mathrm{C}$ respectively in HadGAM and NUGAM). Figure $13 \mathrm{~b}$ shows that, except for NUGEM, the models have a high temporal correlation with the temperature annual cycle ( 0.95), but simulate a larger amplitude of the annual cycle than observed.

In regions SESA, AND, and PAT the observed annual cycles of temperature indicate the cold season from June to September and the warm season from December to March (Fig. 13e, g, i). The coupled and atmosphere-only models are in phase with the observations in these three regions. The amplitude in the simulations is similar to that observed 
in AND and PAT, but in SESA it is larger in all simulations, reflected in higher RMS and standard deviations (Fig. 13f, $\mathrm{h}, \mathrm{j}$ ). All simulations correctly represent the length of the seasons in these regions, with the largest systematic errors occurring in the cold period. The correct simulation of the phase involves high correlation values for the annual cycle (above 0.95 ) and a standard deviation close to that of the observations ensemble (Fig. 13). The similarity of the RMSE in these regions in all simulations illustrates the correctness of the phase adjustment presented by the models in these regions. In the coupled simulations, increasing the resolution reduces the mean annual temperature bias to very small values (lower than $\pm 0.3{ }^{\circ} \mathrm{C}$ ), but this positive impact of horizontal resolution does not occur in the atmosphere-only simulations.

Increasing horizontal resolution in the HadGEM model family does not particularly impact the representation of the annual cycle of temperature in the SA subdomains analyzed. This indicates that, for reducing systematic temperature errors in this family of models, a refinement of the grid only is not sufficient, and improvements in other physical parameterizations are necessary. It is noteworthy that the errors for the average annual temperature are small, less than $\pm 1.5^{\circ} \mathrm{C}$ in all evaluated regions.

\section{Conclusions}

The evaluation of the seasonal climatology of SA shows that the coupled and atmosphere-only models of the HadGEM1 family realistically represent the main climategenerating mechanisms over South America (SACZ, ITCZ, subtropical Atlantic and Pacific highs, and transient systems in subtropical-extratropical latitudes). In general, the coupled models simulate the north-south movement, the intensity and position of the longitudinal band of rain over the equatorial Atlantic of the ITCZ more closely to that observed than do the atmosphere-only models. In coupled models, increased horizontal resolution contributes toward the reduction of the wet bias in the region of the ITCZ, increasing the agreement with the observations on the localization of the rainfall maximum in the Atlantic ITCZ and reducing errors in its north-south displacement. In addition, in the coupled models the patterns of location and strength of the SACZ and the Pacific and the Atlantic subtropical highs are closer to those observed than in atmosphere-only models.

Comparing the seasonal errors in precipitation and temperature, it is noted that the simulations with greater systematic temperature errors on the continent also show, especially in the area of the ITCZ, larger errors in the precipitation; that is, the coupled simulations with more intense rainfall are cooler than the atmospheric simulations.
This indicates a positive feedback between higher rainfall rate and more cloud cover, and consequently, a reduction in the amount of incident radiation, implying a colder troposphere.

In general, the coupled simulation with the highest atmospheric resolution $(60 \mathrm{~km}$ in the atmosphere and $1 / 3^{\circ}$ in the ocean) has systematic errors smaller than the atmospheric simulation for the seasonal precipitation, temperature and circulation fields. In this case, the increase in resolution associated with the ocean-atmosphere coupling, which includes daily variability of SST, provides more realistic simulations of atmospheric patterns observed in South America and the tropical sector of adjacent oceans.

In most of the subdomains analyzed, both coupled and global atmosphere-only models simulate the phase of the annual cycle (dry/rainy and cold/warm seasons) similar to observations. Over the Amazon region the highlight, especially in coupled models, is the better performance of higher resolution simulations in representing the annual rain cycle, thus showing the importance and the positive impact of increased horizontal resolution for precipitation in the continental tropical sector of SA.

The impact of increased horizontal resolution in the HadGEM1 model family on the phase and amplitude of the annual cycle of precipitation and temperature does not present a common pattern in all subdomains. For temperature, the errors of the coupled and atmosphere-only models analyzed here are small over SA-smaller than those reported in other global atmosphere-only models of high horizontal resolution by Blázquez and Nuñez (2012). This indicates that the increase in horizontal resolution is an important factor, but the physical parameterizations in the models are also relevant for realistic simulation of the phenomena described in this paper.

Based on the present results, it can be concluded that for the regions analyzed, the HadGEM1 model family simulate satisfactorily the observed climatology of both precipitation and temperature, and that errors still present are mainly in the magnitude of these variables and can be considered small in comparison to errors found in simulations of other models.

Acknowledgments This research was supported by a collaboration between the University of Reading and the Met Office. The models described were developed from the Met Office Hadley Centre HadGEM1 model by the U.K. High-Resolution Modelling (HiGEM) Project and the UK-Japan Climate Collaboration (UJCC). HiGEM was supported by a NERC High Resolution Climate Modelling Grant (R8/H12/123). UJCC was supported by the Foreign and Commonwealth Office Global Opportunities Fund, and this work was jointly funded by NERC and the Joint DECC/Defra Met Office Hadley Centre Climate Programme (GA01101). Model integrations were performed using the Japanese Earth Simulator supercomputer, supported by JAMSTEC. The authors thank the British Atmospheric Data Centre $[\mathrm{BADC}]$ for hosting the model simulations data. This research was 
partially funded by FAPESP (13/50521-7) linked to the GoAmazon Project. This work was supported by CNPq and CAPES-PROEX, as well.

\section{References}

Ambrizzi T, Hoskins BJ, Hsu HH (1995) Rossby wave propagation and teleconnection patterns in the austral winter. J Atmos Sci 52:3661-3672

Bacmeister JT, Wehner MF, Neale RB, Gettelman A et al (2014) Exploratory high-resolution climate simulations using the Community Atmosphere Model (CAM). J Clim 27:3073-3099

Biasutti M, Sobel AH, Kushnir Y (2006) AGCM precipitation biases in the Tropical Atlantic. J Clim 19:935-958

Blázquez J, Nuñez MN (2012) Performance of a high resolution global model over southern South America. J Clim 33(4):904-919

Bombardi RJ, Carvalho LMV (2009) IPCC global coupled model simulations of the South America monsoon system. Clim Dyn 33:893-916

Brankovic C, Molteni F (1997) Sensitivity of the ECMWF model northern winter climate to model formulation. Clim Dyn 13:75101. doi:10.1007/s003820050154

Carvalho LMV, Jones C, Liebmann B (2004) The South Atlantic convergence zone: intensity, form, persistence, and relationships with intraseasonal to interannual activity and extreme rainfall. J Clim 17:88-108

Cavalcanti IFA, Marengo JA, Satyamurty P, Nobre CA et al (2002) Global climatological features in a simulation using the CPTECCOLA AGCM. J Clim 15:2965-2988

Chen M, Shi W, Xie P, Silva VBS, Kousky VE, Higgins RW, Janowiak JE (2008) Assessing objective techniques for gauge-based analyses of global daily precipitation. J Geophys Res 113:D04110. doi:10.1029/2007JD009132

Cox PM, Betts RA, Bunton C, Essery RLH, Rowntree PR, Smith J (1999) The impact of new land surface physics on the GCM simulation of climate and climate sensitivity. Clim Dyn 15:183-203

Cuadra SV, da Rocha RP (2006) Simulação Numérica do Clima de Verão Sobre o Sudeste do Brasil sua Variabilidade. Revista Brasileira de Meteorologia (Impresso) 21:271-282

Custodio MS, da Rocha RP, Vidale PL (2012) Analysis of precipitation climatology simulated by high resolution coupled global models over the South America. Hydrol Res Lett 6:92-97. doi:10.3178/HRL.6.92

da Rocha RP, Rodrigues CAM, Cuadra SV, Ambrizzi T (2009) Precipitation diurnal cycle and summer climatology assessment over South America: an evaluation of regional climate model version 3 simulations. J Geophys Res. doi:10.1029/2008JD010212

da Rocha RP, Reboita MS, Dutra LMM, Llopart MP, Coppola E (2014) Interannual variability associated with ENSO: present and future climate projections of RegCM4 for South AmericaCORDEX domain. Clim Change 125:95-109

Dee DP, Uppalaa SM, Simmonsa AJ, Berrisforda P et al (2011) The ERA-interim reanalysis: configuration and performance of the data assimilation system. Quart J R Meteorol Soc 137:553-597. doi: $10.1002 /$ aj. 828

Delworth TL, Rosati A, Anderson W, Adcroft AJ et al (2012) Simulated climate and climate change in the GFDL CM2.5 high-resolution coupled climate model. J Clim 25:2755-2781

Demory M-E, Vidale PL, Roberts MJ, Paul B et al (2014) The role of horizontal resolution in simulating drivers of the global hydrological cycle. Clim Dyn 42:2201-2225. doi:10.1007/ s00382-013-1924-4
Diedhiou AS, Machado LAT, Laurent H (2010) Mean kinematic characteristics of synoptic easterly disturbances over the Atlantic. Adv Atmos Sci 27(3):1-17

Gan MA, Kousky VE (1986) Vórtices ciclônicos da alta troposfera no oceano Atlântico Sul. Revista Brasileira de Meteorologia 1:19-28

Gan MA, Rao BV (1991) Surface ciclogenesis over South America. Mon Weather Rev 119:293-302. doi:10.1175/1520-0493(1991)119<1293:SCOSA >2.0.CO;2

Gandu AW, Geisler JE (1991) A primitive equations model study of the effect of topography on the summer circulation over Tropical South America. J Atmos Sci 48:1822-1835

Gandu AD, Silva Dias PL (1998) Impact of tropical heat sources oh the South America tropospheric upper circulation and subsidence. J Geophys Res 103:6001-6015. doi:10.1029/97JD03114

Gates WL, James SB, Curt C, Clyde GD et al (1999) An overview of the results of the Atmospheric Model Intercomparison Project (AMIP I). Bull Am Meteorol Soc 80:29-55

Gomes HB, Ambrizzi T, Herdies DL, Hodges K, da Silva BFP (2015) Easterly wave disturbances over Northeast Brazil: an observational analysis. Adv Meteorol 2015, Article ID 176238. doi: $10.1155 / 2015 / 176238$

Grimm AM, Silva Dias PL (1995) Analysis of tropical-extratropical interactions with influence functions of a barotropic model. J Atmos Sci 52:3538-3555

Gutmann, GJ, Schwerdtfeger WS (1965) The role of the latent and sensible heat for the development of a high pressure system over the subtropical Andes in the summer. Meteorologische Rundschau 18(3):1-17

Hegerl GC, Black E, Richard PA, Ingram WJ et al (2015) Challenges in quantifying changes in the global water cycle. Bull Am Meteorol Soc. doi:10.1175/BAMS-D-13-00212.1

Herdies DL, Kousky V, Ebisuzaki W (2007) The impact of High-resolution SALLJEX data on a global NCEP analysis. J Clim 20: 5765-5783

Hurrel JW, Hack JJ, Boville BA, Willianson DL, Kiehl JT (1998) The dynamical simulation of the NCAR Community Climate Model Version 3 (CCM3). J Clim 11:1207-1236

IPCC (2013) Climate change 2013: the physical science basis. In: Stocker TF, Qin D, Plattner G-K, Tignor M, Allen SK, Boschung J, Nauels A, Xia Y, Bex V, Midgley PM (eds) Contribution of working group I to the fifth assessment report of the intergovernmental panel on climate change. Cambridge University Press, Cambridge. doi:10.1017/CBO9781107415324

Johns TC, Durman CF, Banks HT, Roberts MJ et al (2006) The new Hadley Centre climate model (HadGEM1): evaluation of coupled simulations. J Clim 19:1327-1353

Jung T, Gulev SK, Rudeva I, Soloviov V (2006) Sensitivity of extratropical cyclone characteristics to horizontal resolution in the ECMWF model. Quart J R Meteorol Soc 132(619):1839-1857

Jung T, Miller MJ, Palmer TN, Towers P et al (2012) High-resolution global climate simulations with the ECMWF model in project Athena: experimental design, model climate, and seasonal forecast skill. J Clim 25:3155-3172

Kalnay E, Kanamitsu M, Kistler R, Collins W et al (1996) The NCEP/ NCAR reanalysis project. Bull Am Meteorol Soc 77(3):437-471

Kayano MT (2003) Low-level high-frequency models in the Tropical Atlantic and their relation to precipitation in the Equatorial South America. Meteorol Atmos Phys 83:263-276

Kinter JL III, Cash B, Achuthavarier D, Adams J et al (2013) Revolutionizing climate modeling with project Athena: a multiinstitutional, international collaboration. Bull Am Meteorol Soc 94:231-245

Kodama Y-M (1992) Large-scale common features of sub-tropical precipitation zones (the Baiu Frontal Zone, the SPCZ, and the 
SACZ). Part I: characteristics of subtropical frontal zones. J Meteorol Soc Jpn 70:813-835

Kopparla P, Fischer EM, Hannay C, Knutti R (2013) Improved simulation of extreme precipitation in a high-resolution atmosphere model. Geophys Res Lett 40:5803-5808. doi:10.1002/201 3GL057866

Kousky EV (1980) Diurnal rainfall variation in Northeast Brazil. Mon Weather Rev 108:488-498

Lenters JD, Cook KH (1997) On the origin of the Bolivian high and related circulation features of the South American climate. J Amos Sci 54:656-677

Li J-LF, Martin K, Farrara JD, Mechoso CR (2002) The impact of stratocumulus cloud radiative properties on surface heat fluxes simulated with a general circulation model. Mon Weather Rev 130:1433-1441

Ma CC, Mechoso CR, Robertson AW, Arakawa A (1996) Peruvian stratus clouds and the tropical Pacific circulation: a coupled ocean-atmosphere GCM study. J Clim 9:1635-1645

Ma H-Y, Mechoso CR, Xue Y, Xiao H, Wu C-M, Li J-L, De Sales F (2011) Impact of land surface processes on the South American warm season climate. Clim Dyn 37:187-203. doi:10.1007/ s00382-010-0813-3

Machado LAT, Rossow WB (1993) Structural characteristics and radiative properties of tropical cloud clusters. Mon Weather Rev 121(12):3234-3260

Manganello JV, Hodges KI, Kinter JL, Cash BA et al (2012) Tropical cyclone climatology in a $10-\mathrm{km}$ global atmospheric GCM: toward weather-resolving climate modeling. J Clim 25:3867-3893

Marengo JA, Cavalcanti IFA, Satyamurty P, Trosnikov I et al (2003) Assessment of regional seasonal rainfall predictability using the CPTEC/COLA atmospheric GCM. Clim Dyn 21:459-475. doi:10.1007/s00382-003-0346-0

Martin GM, Ringer MA, Pope VD, Jones A, Dearden C, Hinton TJ (2006) The physical properties of the atmosphere in the new Hadley Centre Global Environmental Model (HadGEM1). Part I: model description and global climatology. J Clim 19:1274-1301

Mclaren AJ, Banks HT, Durman CF, Gregory JM et al (2006) Evaluation of the sea ice simulation in a new coupled atmosphere-ocean climate model (HadGEM1). J Geophys Res 111:C12014. doi:10. 1029/2005JC003033

Misra V, Dirmeyer PA, Kirtman BP (2003) Dynamic downscaling of seasonal simulation over South American. J Clim Boston $16: 103-117$

Mitchell TD, Jones PD (2005) An improved method of constructing a database of monthly climate observations and associated high resolution grids. Int J Climatol 25:693-712. doi:10.1002/ joc. 1181

Mizielinski MS, Roberts MJ, Vidale PL, Schiemann R et al (2014) High resolution global climate modelling; the UPSCALE project, a large simulation campaign. Geosci Model Dev Discuss 7(1): 563-591. ISSN 1991-962X. doi:10.5194/gmdd-7-563-2014

Moura AD, Hastenrath S (2004) Climate prediction for Brazil's Nordeste: performance of empirical and numerical modeling methods. J Clim 17(13):2667-2672

Nobre P, Moura AD, Sun L (2001) Dynamical downscaling of seasonal climate prediction over Nordeste Brazil with ECHAM3 and NCEP's regional spectral models at IRI. Bull Am Meteorol Soc 82:2787-2796

Nobre P, Siqueira L, Almeida R, Malagutti M et al (2013) Climate simulation and change in the Brazilian climate model. J Clim 26:6716-6732

Pope VD, Stratton RA (2002) The processes governing horizontal resolution sensitivity in a climate model. Clim Dyn $19(3-4): 211-236$
Pope VD, Gallani ML, Rowntree PR, Stratton RA (2000) The impact of new physical parametrizations in the Hadley centre climate model-HadAM3. Clim Dyn 16:123-146. doi:10.1007/ s003820050009

Quartly GD, Kyte EA, Srokosz MA, Tsimplis MN (2007) An intercomparison of global oceanic precipitation climatologies. J Geophys Res 112:D10121

Rao VB, Lima M, Franchito SH (1993) Seazonal and interannual variations of rainfall over Eastern Northeast Brazil. J Clim 6:1754-1763

Reboita MS, da Rocha RP, Ambrizzi T, Sugahara S (2010) South Atlantic Ocean cyclogenesis climatology simulated by regional climate model (RegCM3). Clim Dyn 35:1331-1347. doi:10.1007/s00382-009-0668-7

Ringer MA, Martin GM, Greeves CZ, Hinton TJ et al (2006) The physical properties of the atmosphere in the new Hadley Centre Global Environmental Model (HadGEM1). Part II: aspects of variability and regional climate. J Clim 19:1302-1326

Roberts MJ, Clayton A, Demory M-E, Donners J et al (2009) Impact of resolution on the tropical Pacific circulation in a matrix of coupled models. J Clim 22(10): 2541-2556. ISSN 1520-0442. doi:10.1175/2008JCLI2537.1

Sakamoto MS, Ambrizzi T, Poveda G (2011) Moisture sources and life cycle of convective systems over Western Colombia. Adv Meteorol 2011:11

Satyamurty P, Mattos LF, Nobre CA, Silva Dias PL (1998) TropicsSouth America. Meteorology of the Southern Hemisphere. In: Kauly DJ, Vincent DG (eds) Meteorological monograph. American Meteorological Society, Boston, pp 119-139

Seo H, Jochum M, Murtugudde R, Miller AJ, Roads JO (2008) Precipitation from African easterly waves in a coupled model of the tropical Atlantic. J Clim 21:1417-1431. doi:10.1175/2007J CLI1906.1

Seth A, Rojas M (2003) Simulation and sensitivity in a nested modeling system for South America. Part I: reanalyses boundary forcing. J Clim 16:2437-2453

Seth A, Rauscher SA, Camargo SJ, Qian J-H, Pal JS (2007) RegCM3 regional climatologies for South America using reanalysis and ECHAM global model driving fields. Clim Dyn 28:461-480. doi:10.1007/s00382-006-0191-Z

Seth A, Rojas M, Rauscher SA (2010) CMIP3 projected changes in the annual cycle of the South American Monsoon. Clim Change 98(3-4):331

Shaffrey L, Stevens I, Norton W, Roberts MJ et al (2009) UKHiGEM: the new UK high resolution global environment model. Model description and basic evaluation. J Clim 22:1861-1896. doi:10.1175/2008JCLI2508.1

Silva GAM, Dutra LMM, da Rocha RP, Ambrizzi T, Leiva E (2014) Preliminary analysis on the global features of the NCEP CFSv2 seasonal hindcasts. Adv Meteorol 2014, Article ID 695067. doi: $10.1155 / 2014 / 695067$

Small RJ, Bacmeister J, Bailey D, Baker A (2014) A new synoptic scale resolving global climate simulation using the community earth system model. J Adv Model Earth Syst 6:1065-1094. doi:1 $0.1002 / 2014 \mathrm{MS} 000363$

Solomon S, Qin D, Manning M, Chen Z, Marquis M, Averyt KB, Tignor M, Miller HL (2007) Climate change 2007: the physical science basis. Cambridge University Press, Cambridge

Stern W, Miyakoda K (1995) Feasibility of seasonal forecasts inferred from multiple GCM simulations. J Clim 8:1071-1085

Sugahara S, da Rocha RP, Rodrigues MLG (1994) Condições atmosféricas de grande escala associada a jatos de baixos níveis na América do Sul. In: VIII Congresso Brasileiro de Meteorologia, 1994, Belo Horizonte. Anais, vol 2. Sociedade Brasileira de Meteorologia, Rio de Janeiro, pp 573-577 
Torres RR, Ferreira NJ (2011) Case studies of easterly wave disturbances over Northeast Brazil using the Eta Model. Weather Forecast 26:225-235

Uvo CRB, Nobre CA (1989) A Zona de Convergência Intertropical (ZCIT) e a precipitação no norte do Nordeste do Brasil. Parte I: A Posição da ZCIT no Atlântico Equatorial. Climanalise 4(07):34-40

van Haren R, Haarsma RJ, van Oldenborgh GJ, Hazeleger W (2015) Resolution dependence of European precipitation in a state-of-the-art atmospheric general circulation model. J Clim 28:51234-55149
Vera C, Silvestri G, Liebmann B, González P (2006) Climate change scenarios for seasonal precipitation in South America from IPCC-AR4 models. Geophys Res Lett 33:L13707

Waliser DE, Gautier CA (1993) A satellite-derived climatology of the ITCZ. J Clim 6:2162-2174

Xie P, Arkin P (1996) Analysis of global monthly precipitation using gauge observation, satellite estimates, and numerical model predictions. J Clim 9:840-858

Yu JY, Mechoso CR (1999) Links between annual variations of Peruvian stratocumulus clouds and of SST in the eastern equatorial Pacific. J Clim 12:3305-3318 